\title{
Stabilizing selection of seasonal influenza receptor binding in populations with partial immunity
}

James A. Hay ${ }^{1,2}$ Alvin Junus ${ }^{3}$ Steven Riley ${ }^{1}$ Hsiang-Yu Yuan ${ }^{3 *}$

${ }^{1}$ MRC Centre for Global Infectious Disease Analysis

Department of Infectious Disease Epidemiology

School of Public Health

Imperial College London

London, United Kingdom

${ }^{2}$ Center for Communicable Disease Dynamics

Department of Epidemiology

Harvard T. H. Chan School of Public Health

Boston, United States of America

${ }^{3}$ Department of Biomedical Sciences

Jockey Club College of Veterinary Medicine and Life Sciences

City University of Hong Kong

Hong Kong

*Corresponding author Hsiang-Yu Yuan: sean.yuan@cityu.edu.hk 
bioRxiv preprint doi: https://doi. org/10.1101/2020 06.27.175190; this version posted June 29, 2020. The copyright holder for this preprint (which was not certified by peer review) is the author/funder, who has granted bioRxiv a license to display the preprint in perpetuity. It is made available under aCC-BY-NC 4.0 International license.

\begin{abstract}
Mutations that alter cellular receptor binding of influenza hemagglutinin (HA) have profound effects on immune escape. Despite its high mutation rate, it is not fully understood why human influenza HA displays limited antigenic diversity across circulating viruses. We applied phylogenetic analysis and phylodynamic modeling to understand the evolutionary and epidemiological effects of binding avidity adaptation in humans using net charge as a marker for receptor binding avidity. Using 686 human influenza A/H3N2 HA sequences, we found that HA net charge followed an age-specific pattern. Phylogenetic analysis suggested that many binding variants have reduced fitness. Next, we developed an individual-based disease dynamic model embedded with within-host receptor binding adaptation and immune escape in a population with varied partial immunity. The model showed that mean binding avidity was unable to adapt to values that maximized transmissibility due to competing selective forces between within- and between-host levels. Overall, we demonstrated stabilizing selection of virus binding in a population with increasing partial immunity. These findings have potential implications in understanding the evolutionary mechanisms that determine the intensity of seasonal influenza epidemics.
\end{abstract}


bioRxiv preprint doi: https://doi.org/10.1101/2020.06.27.175190; this version posted June 29, 2020. The copyright holder for this preprint (which was not certified by peer review) is the author/funder, who has granted bioRxiv a license to display the preprint in perpetuity. It is made available under aCC-BY-NC 4.0 International license.

\section{Introduction}

Seasonal influenza viruses cause recurrent epidemics due to the repeated emergence of novel antigenic variants ([1], [2]). This is a result of antigenic drift, whereby immune-mediated selection acting on epitope regions of surface glycoprotein hemagglutinin (HA) allows mutant viruses to escape host immunity induced by previous infections or vaccinations.([1], [3]). Although amino acids in the HA globular head domain that change binding to antibodies are directly selected by host immunity during influenza infection, other factors, such as viral attachment to host cells, also play an important role in immune-evasion and may drive influenza antigenic evolution through frequent alteration of cellular-receptor binding avidity ([4], [5], [6], [7]). This mechanism was first supported by a serial passaging study of pandemic A/H1N1, in which cellular receptor binding avidity increased in immune mice and decreased in naive mice ([4]). These observations suggest that an increase in cellular receptor binding avidity might improve immune escape within an immune host, whereas a reduction in binding avidity within a naive host might bear the cost of impeding the efficiency of viral replication or shedding during infection. This indicates that cellular-receptor binding is itself a trait under immune selection in mice, where the phenotypes that maximise within-host fitness differ between immunologically naive individuals and immune individuals.

Whether receptor binding avidity adapts in humans as it does in mice remains unclear. There is a lack of population studies demonstrating if and how influenza virus binding avidity adapts in human populations, where transmission occurs between individuals with a wide range of immune states. Challenges exist because unlike in serial passaging experiments using nasal injections, humans are mainly exposed to a limited number of virus particles during natural exposure through aerosol or contact transmission ([8], [9]). Thus, the chance of successful infection will largely depend on different levels of clinical protection from pre-existing immunity ([10], [11], [12]). Different human infection and vaccination histories would result in a diverse immune spectrum from weak to strong in a population $([[13])$, where transmission between naive, immune and partially immune hosts may depend on and select for different binding avidity phenotypes ([14]).

A consequence of within-host adaptation to heterogeneous immunity in a population is that phenotypic clustering (e.g., receptor binding) of viruses could occur based on the immune status of their hosts: viruses isolated from immunologically similar hosts should be phenotypically more similar than viruses isolated from immunologically dissimilar hosts. Studies have been performed to examine the relationship between phylogenetically distinct viral groups and clinical manifestations or age of the patients but no correlation has been shown $([15],[16])$. However, no study has been performed to examine clustering of receptor binding of 
bioRxiv preprint doi: https://doi org/10.1101/2020.06.27.175190; this version posted June 29, 2020. The copyright holder for this preprint (which was not certified by peer review) is the author/funder, who has granted bioRxiv a license to display the preprint in perpetuity. It is made available under aCC-BY-NC 4.0 International license.

viral isolates based on age-specific immune status of humans or time of isolation. This leaves a number of

31 outstanding questions: is there evidence of influenza receptor binding adaptation to population immunity in the evolutionary history of human influenza viruses? If such adaptation exists, what is its impact on influenza transmission and evolution?

Given the high mutability of influenza ([17], [18]) and frequent occurrence of novel variants within the host ([19], [20]), influenza viruses are paradoxically limited in their genetic and antigenic diversity at the global scale $([21])$. A seminal study discovered that only a few substitutions near the receptor binding site determine much of the major antigenic changes in influenza evolution ([22]). Understanding constraints on influenza antigenic evolution may elucidate the potential impact of antigenic variants on future disease outbreaks. However, little is known about the mechanism by which they are constrained.

To address the above questions, we demonstrate here that binding avidity adaptation is likely present in human populations. Phylogenetic analysis of viral sequences suggested that stabilizing selection exists on cellular receptor binding avidity. We developed an epidemic model embedded with within-host receptor binding adaptation and a population structure with varying degrees of immune status to understand the complex interplay between receptor binding and host immunity and their impact on influenza epidemics. 


\section{Results}

Net charge is a good marker of binding avidity

In order to evaluate whether the adaptation of binding avidity to host immunity can be observed within human influenza infection histories, we first investigated whether changes in the net charge of HA can be used as a molecular marker for binding avidity, as suggested previously ([23] [24]). Because sialic acid receptors on host cells have a negative charge, a positive net charge on viral HA is likely to increase the electrostatic force between the viral HA and its sialic acid receptor $([25])$. We collected amino acid substitutions and their corresponding receptor binding avidity changes that were either publicly available from the literature or from a laboratory conducting experiments. The receptor avidities of the substitutions were measured using agglutination assays with pre-treated neuraminidase as receptor-destroying enzymes (RDE) ([26], [4]). All derived single substitutions were grouped according to whether they reduced (negative), maintained (neutral), or increased (positive) the net charge of the viral HA (Figure 1) by counting the number of positively charged amino acids minus negatively charged amino acids.

Substitutions that led to a higher HA net charge enhanced binding avidity compared to mutations that reduced net charge (Table S1). We estimated the odds ratio of an increase in binding avidity from an increase in net charge relative to a decrease or no change to be 11.27 (95\% confidence interval (CI): 3.14-48.5; p-value $<0.001$ using Fisher's exact test), indicating that net charge is a good marker for HA binding avidity. All p-values were calculated using two-sided tests in this study unless specified otherwise. Compared to a reference virus strain PR8 (A/H1N1), there was also a positive correlation between binding avidity and the net charge of HA (Figure S1.

\section{Net charge correlates to age in humans}

To investigate if binding avidity adaptation is present amongst influenza viruses circulating in humans, we obtained 759 influenza A/H3N2 sequences alongside infected persons' age metadata isolated from 1993-2006 as part of the Influenza Genome Sequencing Project ([27]). The percentage of viruses with a high net charge (defined as an absolute net charge greater than the median value of 18) followed an inverted bell-shaped distribution by age when fitting a smoothing spline (Figure 2). Persons between 20-50 years old (yo) generally had the lowest percentage of virus isolates with high net charge, whereas younger children ( $; 5$ yo) and individuals older than 60 yo exhibited higher percentages of high net charge isolates. 


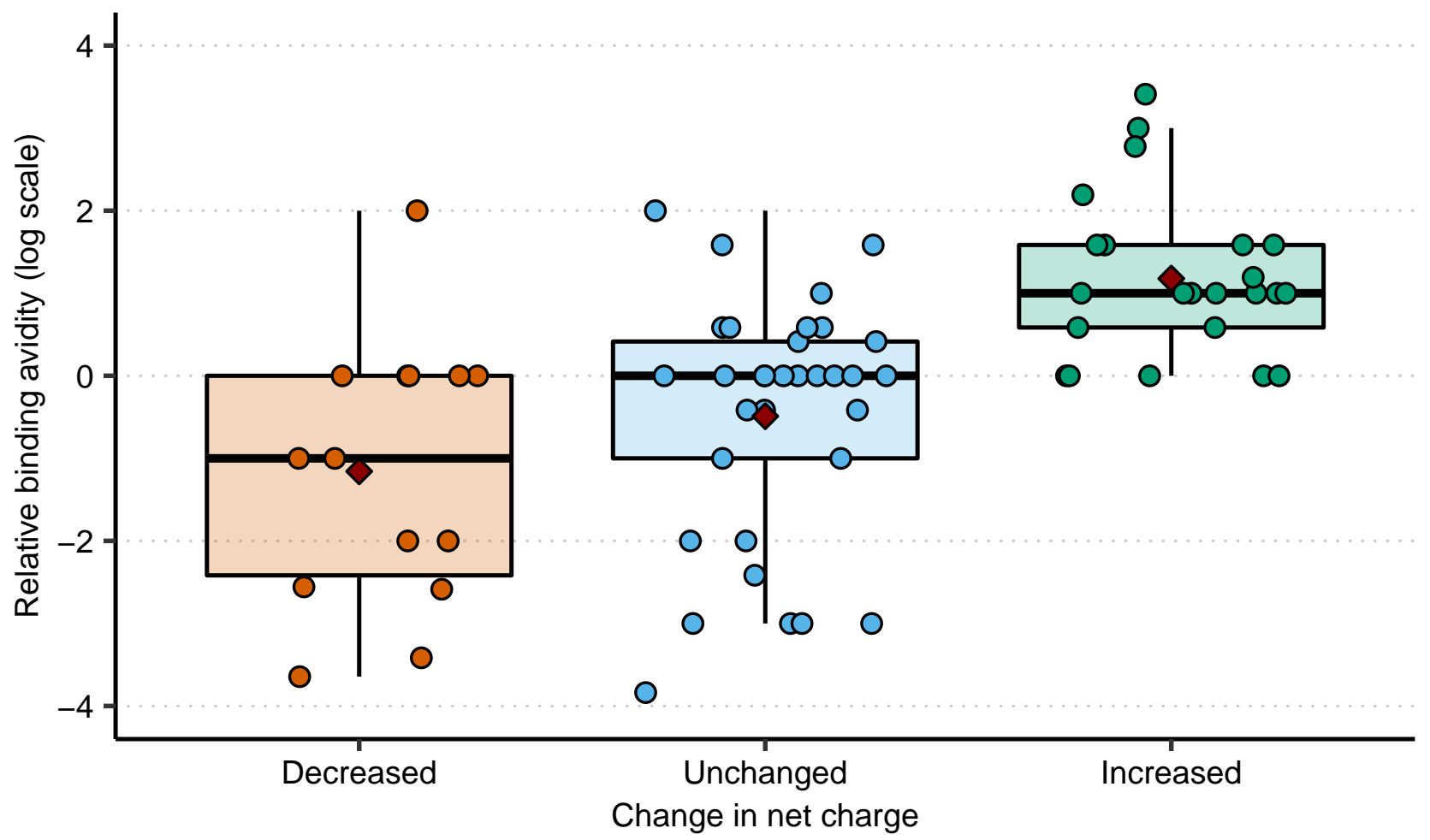

Figure 1 Binding avidity change of single amino acid mutations by net charge. The value is calculated as the $\log$ ratio of RDE activity of the mutant to that of the wild type. Amino acid mutations are grouped into 3 categories. Increase represents amino acid changes that increase net charge by 1 or 2 units. Decrease represents the amino acid changes that decrease net charge by 1 or 2 units. Unchanged represents amino acid changes that do not change net charge. Aspartate (D), glutamate (E) were counted as negatively charged amino acids (-1) and Histidine $(\mathrm{H})$, Arginine $(\mathrm{R})$, Lysine $(\mathrm{K})$ were counted as positively charged $(+1)$. Diamonds show mean values.

ages from these human virus isolates showed similar patterns to age specific serological prevalence. Antibody titers against the hemagglutinin head of current influenza A/H3N2 strains are highest in children and the elderly, and lowest in middle aged individuals ([29] [30] [31] [32]). The observed age differences in seroprevalence could be a consequence of original antigenic sin and non-HA targeted immunity leading to lower antibody titers in adults relative to children, and more lifetime exposures with higher vaccination rates in the elderly. These data support the binding avidity hypothesis that a higher binding avidity would be selected for by higher levels of host immunity in a human population as a result of adaptation for immune escape ([4]).

\section{Phylogenetic analysis of A/H3N2}

To further investigate whether binding avidity alterations occurred frequently among transmission events in A/H3N2 infection histories, we used 686 (a subset of the full 759) viral sequences isolated from North America 87 (including sequences from the Influenza Genome Sequencing Project) and reconstructed the phylogenetic tree using BEAST ([33] $)$. The ancestral states of the nucleotides in internal nodes were also inferred during 


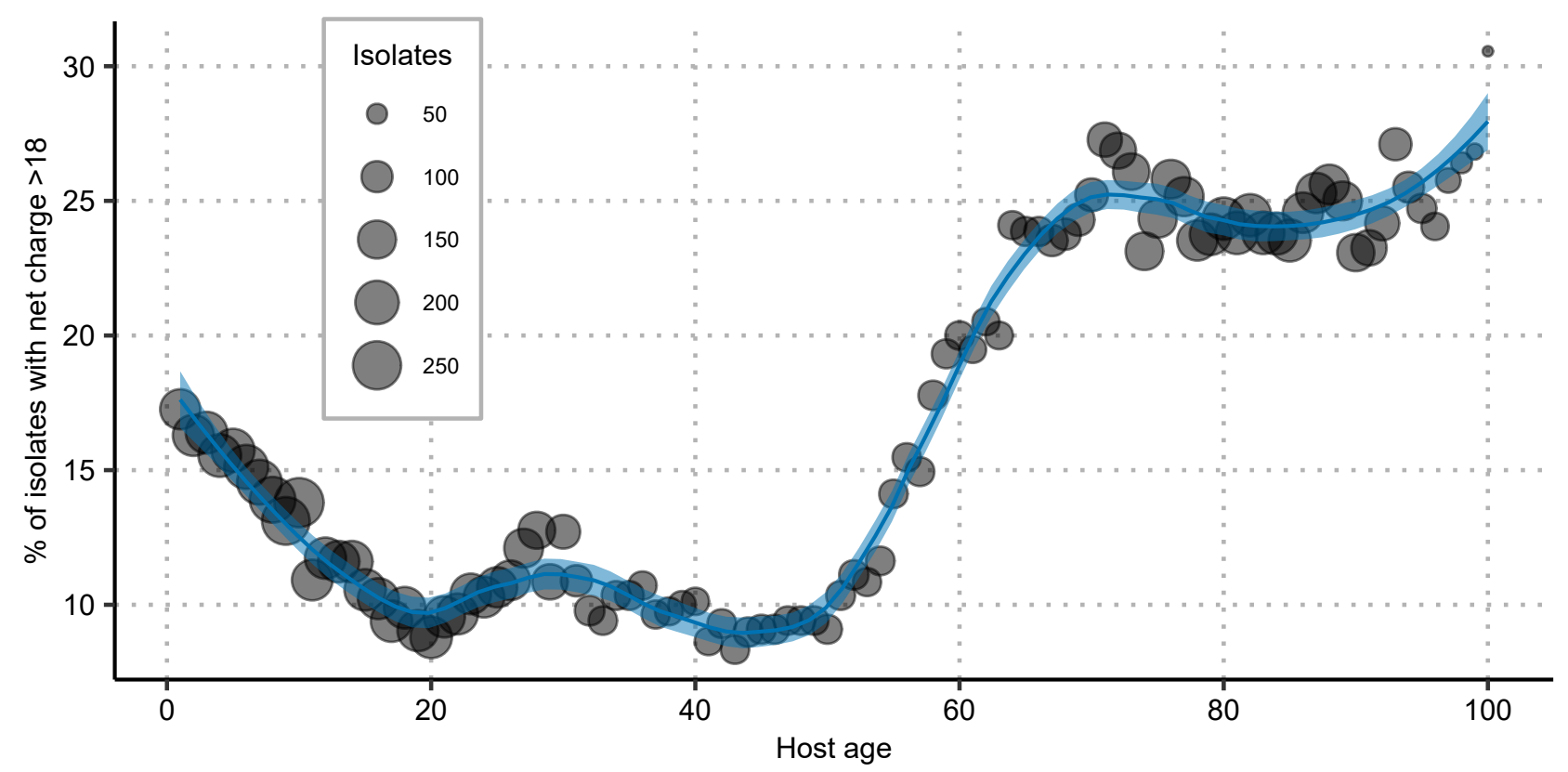

Figure 2 Percentage of high net charge viral isolates by age. Each circle represents the proportion of individuals with high net charge isolates $(>18$ where median net charge is 17) calculated using a sliding window of size 10 years centered on each year from 1 to 100 yo. The size of circle represents the number of strains in a given sliding window. A smooth curve (blue line) was fitted with the calculated values by LOESS regression using a span value of 0.3 . 759 virus sequences and age metadata were obtained from the Influenza Genome Sequencing Project ([27]) and the Influenza Virus Resource Database ([28]).

Bayesian reconstruction and were then transformed to amino acid sequences. While we observed changes in net charge between different clades, we did not observe frequent sequential alterations within clades (Figure $3 \mathrm{~A}$ ). 
A
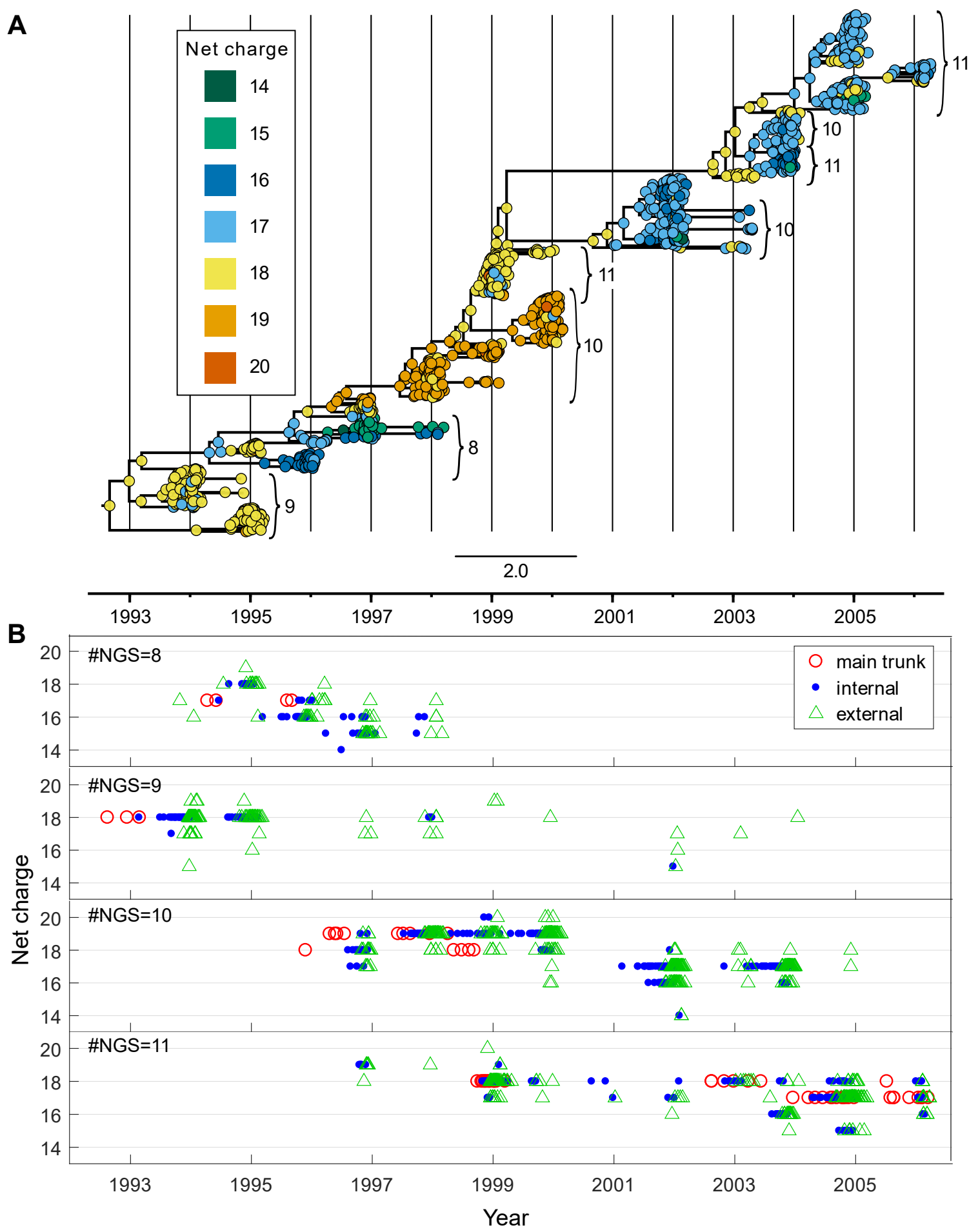

Figure 3 Phylogenetic analysis of cellular receptor binding avidity. (A) The maximum clade credibility (MCC) tree for the A/H3N2 viral isolates from New York State, with HA net charge values mapped onto all inferred internal nodes and all observed external nodes. Numbers next to the bracketed clades denote the \#NGS group. (B) Viral net charge dynamics over time. Each point represents a node from (A) and is colored by whether it is classified as an internal main trunk node (red circle), an internal non-trunk node (blue dot), or an external node (green triangle). Placement along the x-axis corresponds to the inferred or observed time of the node in the phylogeny. Placement along the y-axis corresponds to calculated net charge value. Each of the four subplots shows viral net charge dynamics for a single \#NGS group. 
A lower number of net charge-produced binding mutations were found in internal nodes than external nodes (Figure $3 \mathrm{~B}$ ). Across all internal nodes, $7.7 \%$ of the strains showed net charge changes relative to the reconstructed ancestral sequence; however, a higher proportion of external nodes $(12.1 \%)$ demonstrated changes in net charge (Table S2). Nodes that demonstrated changes in net charge were approximately $40 \%$ less frequent in internal than external nodes. Normalizing by total branch length for internal and external branches yielded similar results, with fewer net charge changes occurring per unit time on internal relative to external branches. The odds ratio for a change in net charge for strains at external nodes relative to internal nodes was 1.64 (95\% CI: 1.14-2.35; Fisher's exact test; $\mathrm{p}$-value=0.009; $\mathrm{n}=1370$ ). Since external nodes are more likely to die out than internal nodes, these data suggest that many strains with HA binding avidity changes (with avidities that are too high or too low) may have reduced fitness in the population, which is a key characteristic of stabilizing selection.

\section{The impact of binding avidity adaptation on epidemic dynamics}

To measure the role of binding avidity in an influenza epidemic, we first evaluated the impact of binding avidity adaptation on epidemic dynamics using an individual-based (also called agent-based) model to compare the scenarios where the binding avidity trait was or was not allowed to undergo within-host adaptation. Within-host binding avidity adaptation was determined by the within-host fitness gradient conditional on the immunity of the host (Figure 4A), such that binding avidity changed towards the value that maximized the within-host reproductive number during an infection. We assumed that rapid evolution and limited intrahost genetic diversification through new mutations was present ([20]), and therefore we only recorded a single binding avidity trait to represent the virus population in an infected individual. Given a contact, the corresponding probabilities of infection at different levels of host immunity were also determined (Figure $4 \mathrm{~B}$ ). Both within-host fitness and the probability of infection reached a maximum at the same virus binding avidity, indicating that binding avidity adaptation increased not only virus reproduction within a host but also transmission probability between hosts. We therefore hypothesized that binding avidity adaptation would increase incidence during an epidemic.

We simulated disease dynamics after introducing an antigenically novel virus into a population with varying degrees of pre-existing partial immunity. Incidence reached a peak approximately 200 days after seeding with an antigenically novel virus when the model allowed binding avidity to undergo within-host adaptation (Figure 5A). Regardless of the assumed binding avidity of the initial seed virus, mean binding avidity across extant viruses quickly adapted to a relatively low value (near 0.45 ) within the first 30 days of the epidemic, indicating 
A

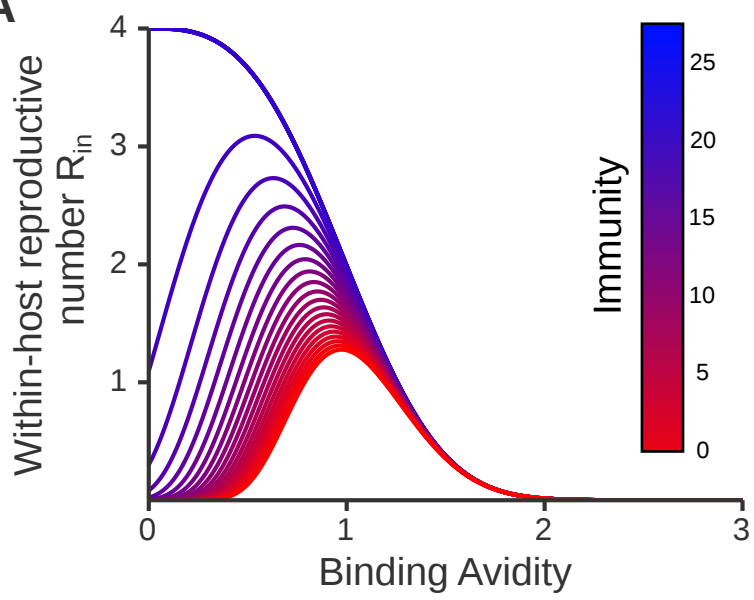

B

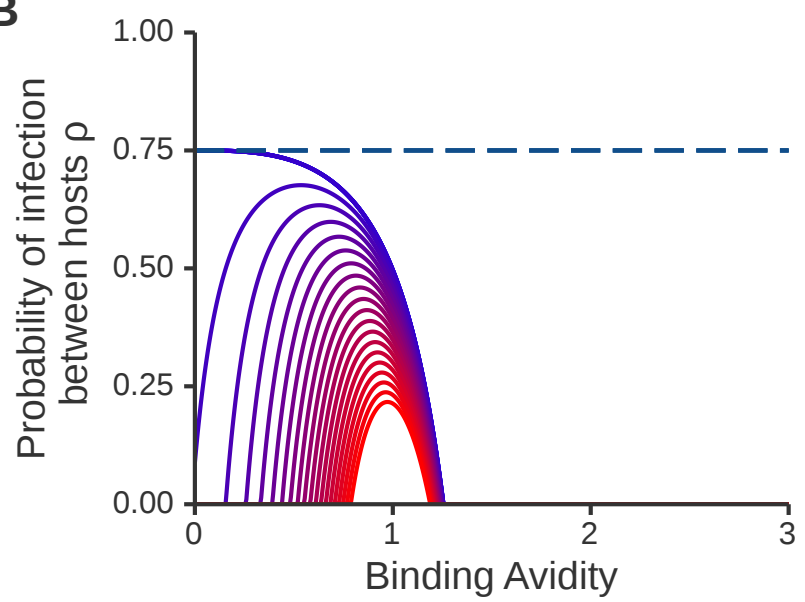

Figure 4 Within-host reproductive number and the probability of infection. (A) Within-host fitness represented by the expected within-host reproductive number $R_{i n}$. Parameters for within-host immune escape and replication cost were set as $p=4, r=70, a=0.7$ and $b=3$, and the effective number of virions produced per replication was $n=4$ (see Table $\mathrm{S} 4$ for parameter descriptions). Blue indicates infection in an immunologically naive host, whereas red indicates a host with stronger immunity. (B) The probability of infection to a susceptible host. Within-host parameters values are the same as in (A) and the effective number of transmitted virions was $\sigma=1$.

rapid adaptation to the lower initial population immunity. Later, mean binding avidity gradually increased toward a higher value (near 0.70) from 50 to 400 days after seeding (Figure S3). This increase in mean binding avidity correlated with an increase in average population immunity (Figure $5 \mathrm{~B}$ ), indicating adaptation to the gradual accumulation of host immunity during the epidemic. The number of immunologically naive individuals (defined as having no immunity against the infecting virus) involved in transmission dropped as successful infections increased the number of people with partial immunity. Therefore, successful infections later in the 
bioRxiv preprint doi: https://doi.org/10.1101/2020.06.27.175190; this version posted June 29, 2020. The copyright holder for this preprint (which was not certified by peer review) is the author/funder, who has granted bioRxiv a license to display the preprint in perpetuity. It is made available under aCC-BY-NC 4.0 International license.
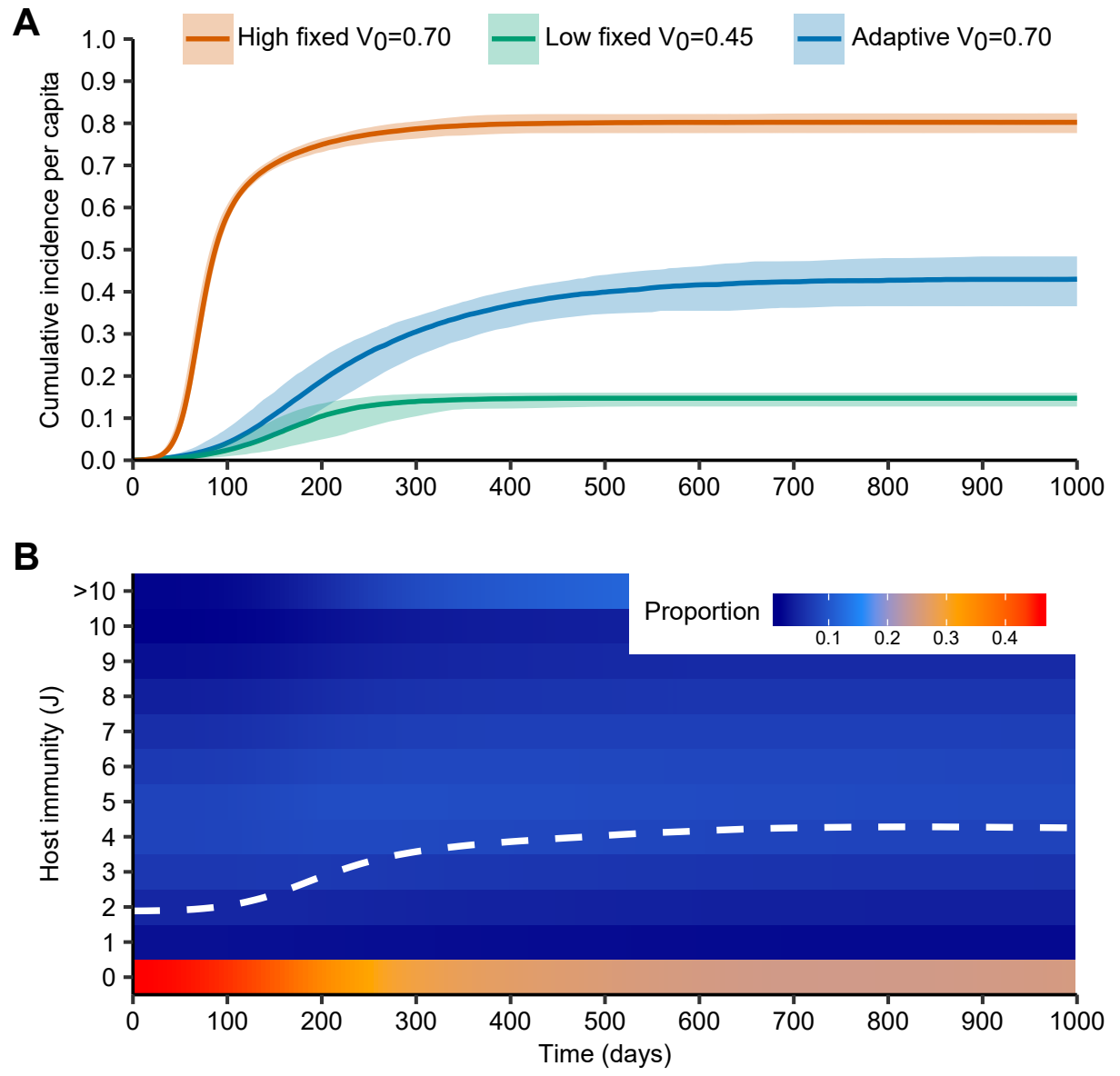

Figure 5 Dynamics of simulated epidemics with and without within-host binding avidity adaptation. (A) Median (lines) and 95\% quantiles (shaded regions) of cumulative incidence per capita from 200 simulated epidemics after introduction of an antigenically novel strain into a population size $N=500,000$. Blue line shows simulated incidence when binding avidity was allowed to adapt within hosts over the course of the epidemic, starting at a binding avidity of $V_{0}=0.70$. Orange line shows incidence with binding avidity fixed at values adapted for transmission in a high immunity population $V=0.70$. Green line shows the incidence with binding avidity fixed at values adapted for transmission in a low immunity population $V=0.45$. Remaining epidemiological parameters are described in Table S4. (B) Distribution of population partial immunity during the epidemic from one simulation with binding avidity adaptation. Colours show the proportion of susceptible hosts with a given level of host immunity against the seed virus, $J$, over time. White line represents mean population immunity. 
To understand the impact of binding avidity adaptation on epidemic dynamics, we compared the simulations

with ongoing binding avidity adaptation to simulated epidemics with binding avidity fixed at the lower early-phase adapted value (0.45) and the higher late-phase adapted value (0.70) (Figure 5A). Epidemics with binding avidity adaptation demonstrated higher attack rates relative to simulated epidemics with binding avidity fixed at a lower value (mean of simulations $=43.0 \%$, standard deviation $=2.86 \%$ vs. $14.6 \%$, standard deviation $=0.83 \%)$. This was due to the gradual increase of binding avidity alongside increasing population immunity, which increased the relative reproductive success of the virus population. However, attack rates under the binding avidity adaptation simulations were lower than in epidemics with binding avidity fixed at the late-phase adapted value $($ mean of simulations $=80.2 \%$, standard deviation $=1.16 \%$ ), indicating reduced fitness. This reduction in incidence contradicts the initial hypothesis that binding avidity adaptation should invariably lead to more transmission events during the epidemic.

\section{Binding avidity adaptation reduces population fitness}

We next compared the observed mean binding avidity to the theoretical population-level optimum binding avidity over the course of the epidemic to explain why within-host binding avidity adaptation resulted in reduced transmission relative to binding avidity fixed at the late-phase adapted value. Optimum binding avidity was calculated as the avidity at which the largest number of infected individuals would be produced in the population, as measured by the effective reproductive number $R_{t}$. During the outbreak, the optimum binding avidity gradually increased to a higher level due to the accumulation of partial immunity in potential hosts. However, we observed that the mean binding avidity of viruses among infected individuals, both before (at the time of infection) and after within-host adaptation (at the end of the infectious period), was lower than the population-level optimum binding avidity and provided lower population-level fitness (Figure 6). In addition, the mean binding avidity measured after within-host adaption (measured at the end of the infectious period) tended to be even lower, corresponding to a lower $\left(R_{t}\right)$ than at the start of the infectious period. This could explain why a lower proportion of high net charge isolates and lower average net charge were observed in the external nodes of the previous phylogenetic tree (Table $\mathbf{S 2}$ ).

\section{Stabilizing selection of binding avidity on the viral phylogeny}

Stabilizing selection of binding avidity was demonstrated by comparing the binding avidity values at the internal and external nodes of viral phylogenies reconstructed from our model simulations. While mean binding 162 avidity tended to increase over time, many of the viruses that adapted to much lower binding avidities were 
bioRxiv preprint doi: https//doi.org/10.1101/2020.06.27.175190; this version posted June 29, 2020. The copyright holder for this preprint (which was not certified by peer review) is the author/funder, who has granted bioRxiv a license to display the preprint in perpetuity. It is made available under aCC-BY-NC 4.0 International license.

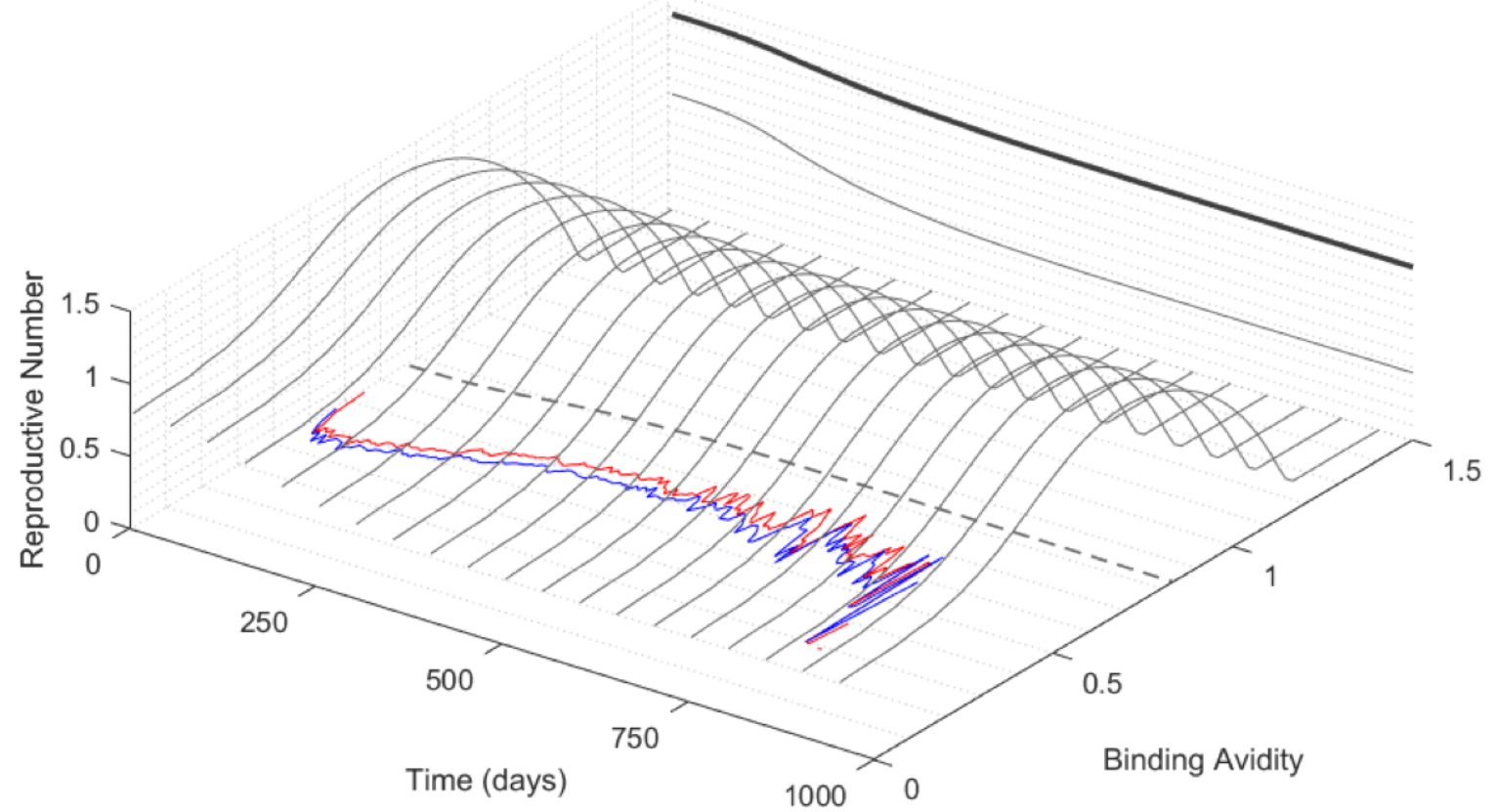

Figure 6 Change of mean binding avidity and effective reproductive number over time. Optimum binding avidity (dotted line) is calculated as the avidity that produces the largest number of infected individuals at the population level, measured by the effective reproductive number $R_{t}$. The maximum $R_{t}$ (bold gray line) was produced by the optimum binding avidity whereas the lower $R_{t}$ (thin gray line) was produced by binding avidity fixed at 0 . The red line shows the mean binding avidity across all extant viruses before within-host adaptation (at the start of each individual's infectious period). The blue line shows the mean adapted binding avidity across all extant viruses after within-host adaptation (at the end of the infectious period). The bell-shaped curves represent $R_{t}$ at different binding avidities at 50 day intervals.

present as external tips, which were more likely to die out without onward transmission relative to internal tips (Figure 7 and Figure S4). This suggests a deleterious effect on the virus population. To further understand whether most of the binding avidity changes produced through within-host adaptation were deleterious, we defined a threshold $(\Delta V>0.3)$ for significant binding avidity change, and found that external tips in simulated viral phylogenies contained more frequent significant changes (Table S3), similar to the pattern generated by the influenza A/H3N2 sequence data (Table S2). These observations suggest that although many large changes in binding avidity allowed the virus to infect or adapt to more immunologically naive susceptible hosts, the opportunity for the virus to further transmit was lowered in a population with partial immunity. When comparing binding avidity changes between internal (lineages that persisted) and external nodes (lineages that died out) (Figure 8), changes in binding avidity of internal nodes narrowed towards the mean. Nodes in the main lineage were selected to have weaker or near zero binding avidity changes (Figure S7). These results demonstrate a typical pattern of stabilizing selection during an outbreak ([34], [35], [36]). 
bioRxiv preprint doi: https://doi.org/10.1101/2020.06.27.175190; this version posted June 29, 2020. The copyright holder for this preprint (which was not certified by peer review) is the author/funder, who has granted bioRxiv a license to display the preprint in perpetuity. It is made available under aCC-BY-NC 4.0 International license.

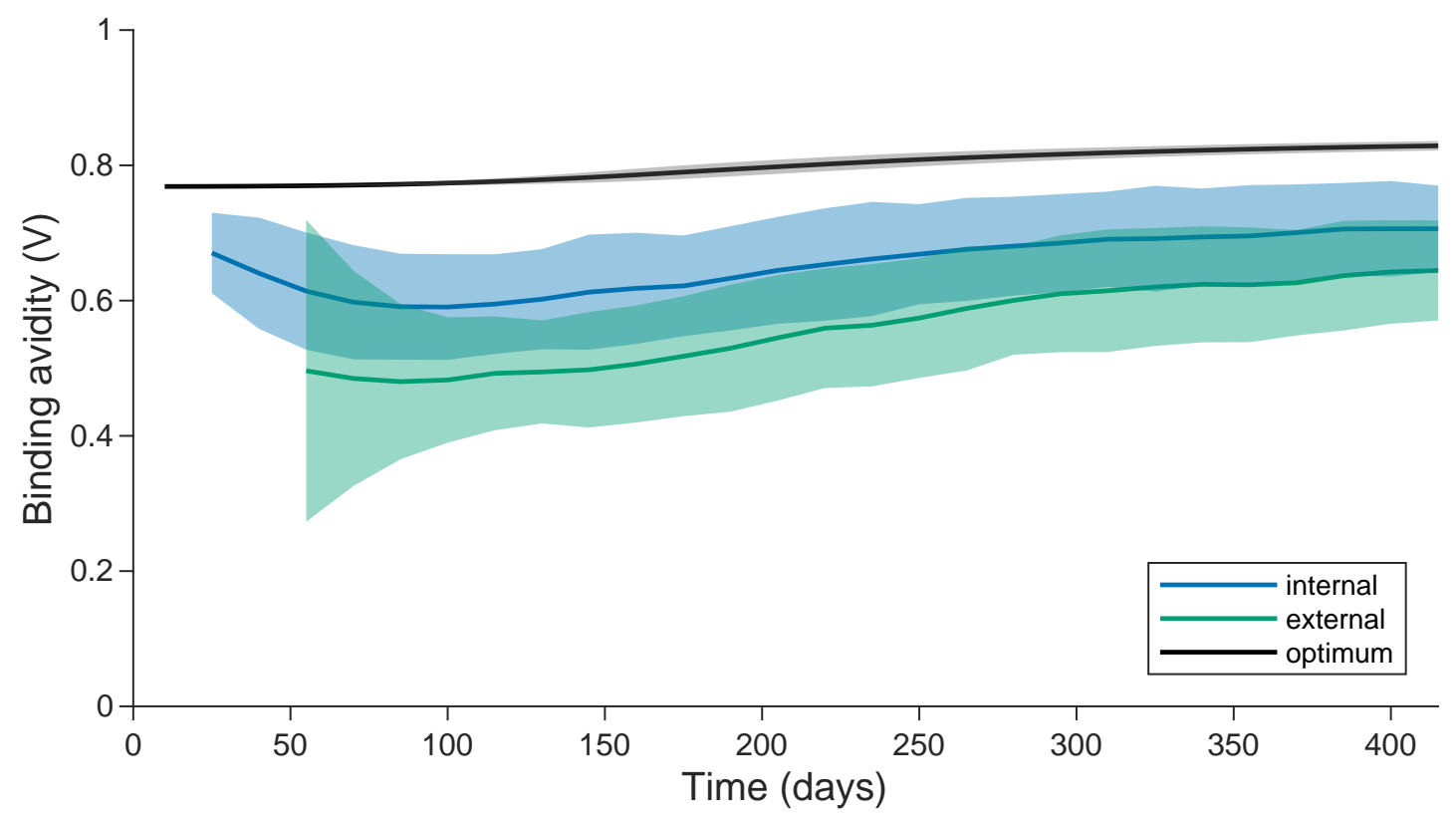

Figure 7 The deleterious effect of within-host binding avidity adaptation on simulated viral phylogenies. The viral phylogenies were produced from the model using 200 simulations. A single viral phylogeny with ancestor nodes was reconstructed from each simulation. Blue represents internal nodes and green represents external tips from the viral phylogeny. Gray represents the optimum virus binding avidity that could produce the highest effective reproductive number $R_{t}$. Solid line denotes the mean value and the shaded area represents $95 \%$ quantiles.

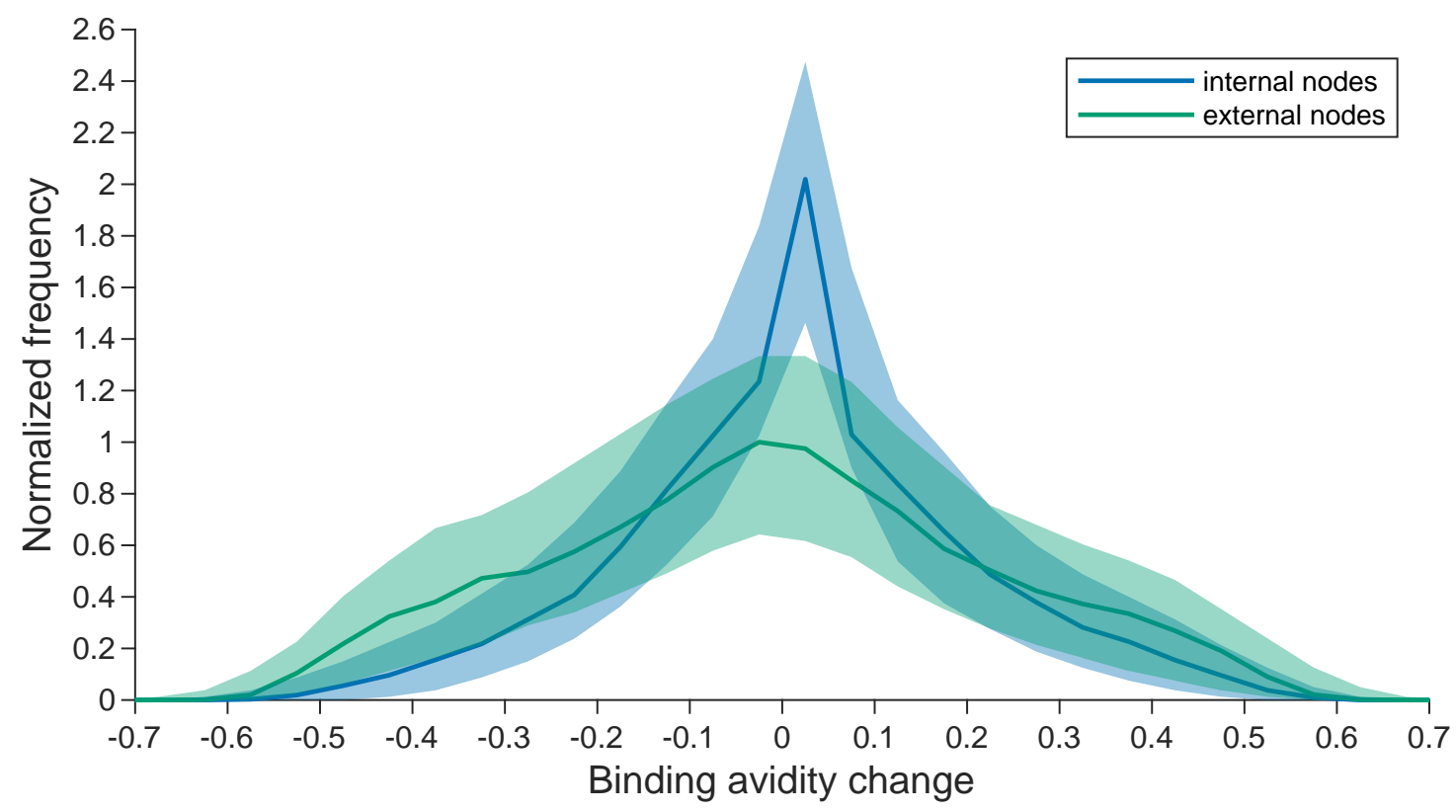

Figure 8 Changes in binding avidity of internal and external nodes (lineages that persisted and died out respectively), averaged from 200 simulated phylogenetic trees. Each simulated tree was randomly thinned to contain 300 external nodes. Y-axis denotes the absolute frequency divided by the mode for external nodes. 


\section{Discussion}

Following experimental support for the functional role of cellular receptor binding avidity in immune escape

and antigenic drift ([4],[37], [38]), a recent study demonstrated that only a small number of potential

substitution sites in the HA head, all near the receptor binding site, are responsible for most of the observed

variation in the evolutionary history of influenza A/H3N2 ([22]). Later, deep sequencing studies revealed that 
tree. The selective pressures during an epidemic can be explained as a combination of directional selection acting on a longer time scale (during the epidemic) and stabilizing selection acting on a shorter time scale (during each single infection) using our model simulation results. The selection for a higher mean binding

In order to understand the interplay between immune response and receptor binding evolution, we developed an 217 individual-based epidemic model incorporating within-host virus binding avidity adaptation and individual immune boosting. The model allowed us to produce a simulated viral phylogeny and to observe changes of binding avidity alongside changes in individual host immunity over time. Although recent developments of multi-scale, immuno-epidemiological models allow a better understanding of the impact of within-host dynamics on population-level quantities ([42], [43]), partial and stratified immunity, which could influence epidemic dynamics ([11]), have not been fully considered in these models. We have provided here empirical and theoretical support for stabilizing selection acting on binding avidity in human populations with varying degrees of partial immunity.

Our analysis is subject to a number of limitations, and alternative hypotheses exist which challenge some of our 226 assumptions. First, our dataset contained a relatively small number of full-length sequences. Further work external and internal nodes is reproducible. Second, we assumed that within-host immune selection was possible throughout the time course of an infection in our model. Recent theoretical work has proposed a lack of antibody-mediated selection during influenza viral replication because viral growth largely subsides before a humoral antibody response is mounted; antigenic selection instead occurs at the point of transmission via secretory IgA on mucosal surfaces ([44]). The authors suggest that this mechanism can limit population-level diversification because the probability of a novel variant successfully infecting an immunologically experienced 
act on receptor binding avidity during viral replication whereas selection for immune escape may occur immunity may differ to variants that are successful replicators. Third, our simulation results required parameter values to be chosen to reflect within-host dynamics. We chose parameters to qualitatively reflect influenza epidemiology and natural history (e.g. infectious period, distribution of population immunity), but it was not possible to choose all parameters based on empirical data.

Short-sighted evolution of RNA viruses has been observed in recent years, particularly in chronic viral infections such as HIV and HCV, which have long transmission intervals ([45]). Lythgoe et al. demonstrated that HIV evolution is "short-sighted" because what is good for the virus in the short-term within the host is not necessarily good for the virus in the long-term at the epidemiological level. Thus, the selective advantage of a viral trait differs at the within-host and between-host level. However, for rapidly evolving viruses which have short transmission intervals, like influenza, it has been suggested that little short-sighted evolution should be possible because there is only a short window of time for within-host adaptation before onward transmission or viral clearance $([46])$. Our results suggest that within-host binding avidity adaptation to a very low value or a very high value in individuals with immunologically naive or strong partial immunity becomes detrimental to the survival of a viral lineage in a population with pre-existing partial immunity. Binding avidity adaptation as a trait may therefore be selected against to reduce short-sighted evolution. Whether the short infection duration of influenza coupled with a high transmission rate is a consequence of short-sighted evolution is an open question.

Deleterious mutations have been proposed to affect influenza evolution and antigenic drift ([47], [48]). This mechanism would require a sufficiently large number of mutations with detrimental effects. Mutations that affect protein stability can be produced ([49]), but given a high mutation rate and rapid rate of evolution within a host, the percentage of deleterious mutations would be expected to be low due to positive selection. Our results are not inconsistent with the proposed effects from deleterious mutations. Because partial and stratified immunity develops during an epidemic, many immune escape mutations led by binding avidity changes within a host will reduce the effective reproductive number at the population level and behave like deleterious mutations due to the trade-off between adaptation at the within and between host scales. This explains why many antigenic or immune escape substitutions may not become fixed in a population even when they would be expected to have a strong fitness advantage [39]. 
bioRxiv preprint doi: https://doi.org/10.1101/2020.06.27.175190; this version posted June 29, 2020. The copyright holder for this preprint (which was not certified by peer review) is the author/funder, who has granted bioRxiv a license to display the preprint in perpetuity. It is made available under aCC-BY-NC 4.0 International license.

binding avidity assays in addition to serological tests in order to prioritize the groups that should be vaccinated to reduce overall disease incidence and understand constraints on influenza antigenic evolution or antigenic 267 drift ([50], [14]). Understanding the effect of binding avidity on both epidemic and evolutionary dynamics 268 would be beneficial for influenza outbreak future prediction and control. 


\section{Material \& Methods}

Analysis of HA cellular receptor binding avidity

The RDE binding avidity for amino acid changes were collected from the literature ([4] [6] [5] [38]) and also $\mathrm{A} / \mathrm{H} 1 \mathrm{~N} 1$ and 3 from A/H3N2, were collected (Table S5). After removing 3 duplicates and 1 reversed mutation, 274 there were 70 mutants, including 49 single, 20 double and 1 triple amino acid changes. For the RDE binding 275 avidity assays present in the literature, the magnitude of each change was extracted using the Web Plot Digitizer 276 ([51]). The effect of each single amino acid change (including secondary and tertiary changes) on binding 277 avidity was calculated as the log ratio of RDE activity of the mutant compared to the wild type. Binding avidity 278 against the actual net charge of HA from each mutant strain was calculated as the log ratio of RDE activity of 279 the A/H1N1 mutants ( $\mathrm{n}=67$ ) relative to wild type influenza A virus (strain A/Puerto Rico/8/1934 A/H1N1), also 280 called PR8.

\section{Calculating net charge of influenza HA}

Influenza virus sequences isolated from New York State as part of the Influenza Genome Sequencing Project ([27]) along with the exact date of isolation and clinical metadata on host age were collected from the Influenza Virus Resource Database ([28]). Among total 759 isolates, we used 686 full-length influenza A/H3N2 HA sequences, isolated between July 1993 and June 2006. Changes in net charge relative to reconstructed ancestral sequences were estimated by summing the total number of positively charged amino acids minus the number of negatively charged amino acids. Amino acid such as Arginine (R), Histidine (H) and Lysine (K) are positively charged whereas Aspartic acid (E) and Glutamic acid (D) are negatively charged. For estimating net charge from the isolated viral HA sequences, net charge was calculated from the sequences using amino acid positions 17 through 345 of the HA, which define the protein's globular head domain (HA1). We specifically did not calculate net charge values using only the amino acid positions that comprise the cellular receptor binding site because charge at other sites in the globular head domain still impact electrostatic forces and therefore binding avidity.

Phylogenetic trees were reconstructed using the software BEAST ([52]), under a general time reversible (GTR) 296 model with gamma distributed rate variation and a proportion of invariant sites. $10^{7}$ Markov chain Monte Carlo (MCMC) steps were sufficient in reaching high effective sample sizes $(>100)$. From each viral subtype's 
BEAST produced multiple possible ancestor sequences, consensus sequences were calculated with a

BLOSUM50 scoring matrix using Matlab Bioinformatics Toolbox. For all the sequences at internal and external nodes we calculated net charge as described above.

We developed a stochastic Susceptible-Infected-Recovered-Susceptible (SIRS) individual-based model and viruses ([11]). The status of each individual host could be changed from $S$ to $I, I$ to $R$ with short-term full protection with respect to infection, and from $R$ to $S$ with partial immunity $J$ (Figure S5A). At the time of contact between a susceptible and infected host, the probability of infection $\rho$ was determined by host immunity against the challenging source virus and its binding avidity as described below. Properties of viruses, including receptor binding avidity changes $V$ and antigenic distance $\delta$, were tracked within hosts and between each transmission event (Figure 5 B 3 ). For computational reasons, we simulated one virus object per infection, such that each virus represented the average of all individual virions in that virus population during infection in a host. All epidemiological parameter definitions and assumed values, including births and deaths at rate $\mu$, the infectious period $1 / \gamma$, short-term full immunity that wanes at rate $\omega$, contact rate $c$, etc., are shown in Table $\mathbf{S} 4$.

The model and code are openly available and documented as an R-package with a $\mathrm{C}++$ back-end at of epidemiological mechanisms that we do not consider in these analyses (e.g., antigenic drift, antigenic change 317 as a by-product of binding avidity adaptation, multi-season dynamics). We restricted the analyses here to described in the Supplementary Methods.

\section{Stratified host immunity}

In the model, host immunity determined the probability of success of two events: (i) infection during a transmission event and (ii) within-host replication during the course of an infection. Host immunity was determined by the contents of an individual's infection infection history, $\mathbf{h}$, and their homologous antibody titer, $j$. We defined an infection history $\mathbf{h}$ as the set of all $n$ viruses that an individual had previously been infected with:

$$
\mathbf{h}=\left\{v_{1}, v_{2}, \ldots v_{n}\right\}
$$

where $v_{n}$ represents virus $n$. When calculating the probability of infection during a contact (the first event), the effective immunity of a susceptible host $i$ against infection from the source virus in an infectious host $s$ was 
given by the total antibody titer less the smallest antigenic distance of the source virus $v_{s}$ (i.e., from host $s$ ) to

$$
J_{i}=\max \left(0, j_{i}-\delta_{i s}\right)
$$

where $\delta_{i s}=\min \left(\delta_{l s}\right)$ for $l \in \mathbf{h}_{i}$; and $j_{i}$ is the homologous titer of host $i$ against any strains that they had previously been infected with (Figure S5A).

Determining host immunity to calculate the within-host reproductive success of a virus (the second event) was defined in a similar way: the measure of host immunity for an infected host $i$ was $J_{i}=\max \left(0, j_{i}-\delta_{i}\right)$, where $\delta_{i}$ is the smallest antigenic distance of the virus infecting host $i$ relative to all viruses that previously infected host $i$ (i.e., antigenic distance to self) (Figure $\mathbf{S 6}$ ).

In these analyses, we assumed that only one initial antigenically novel virus strain was seeded in 100 initially ${ }_{337}$ infected individuals $\left(I_{t=0}=100\right)$ and no further antigenic mutations occurred during the epidemic. All individuals in the initial population were assumed to have the same infection history such that $\delta_{i s}=\delta_{i}=3$ for all viruses and hosts at the start of the simulation. Thus, all instances of $\delta_{i s}$ and $\delta_{i}$ were either 0 or 3 depending on whether the host had been previously infected with the novel virus or not. Similarly, infection histories could be either $\mathbf{h}=\emptyset$ (empty infection history at birth or the start of the simulation) or $\mathbf{h}=\left\{v_{1}\right\}$ (infected with the seed virus one or more times). However, individuals could have different pre-existing immunity. $J$ can be considered analogous to immunity as determined by antibody titers ([32] [11]). The definition of antigenic distance used here is analogous to previous definitions ([1]).

We assumed that recovery generated an antibody boost drawn from a Poisson distribution ([11]) and that the level of realised boosting was inversely proportional to the pre-existing antibody titer, representing a ceiling effect on antibody responses $([53])$. Antibody boosting was therefore given as:

$$
k \sim \operatorname{Poisson}\left(\psi-\frac{\psi}{j_{\max }} j\right)
$$

where $j$ is the antibody titer before boosting; $\psi$ is the mean antibody boost from a starting titer of 0 ; and $j_{\max }$ is 350 the maximum achievable antibody titer. The boosted antibody titer following recovery was therefore given as 351 $j^{\prime}=j+k$. Figure $\mathrm{S} 6$ shows an example of how an individual host's immunity changes over time following 352 single or multiple infections. Hosts could be infected any number of times, but the probability of re-infection 353 
decreased as host immunity increased following recovery.

Similarly, once host $i$ recovered from infection, that virus was added to $i$ 's infection history such that:

$$
\mathbf{h}_{i}^{\prime}=\mathbf{h}_{i} \cup\left\{v_{s}\right\}
$$

\section{Probability of infection}

In the stochastic model, each time a source virus came into contact with a susceptible host, the probability of successfully infecting that host was defined as:

$$
\rho=1-\frac{1}{R_{\text {in }}^{\sigma}}
$$

where $R_{i n}$ was the within-host reproductive number and $\sigma$ was the effective number of infectious particles initially transmitted. Note that although the effective number of infectious particles can be $>1$, this number only affects the probability of a single infection event during transmission and only one virus object was simulated for each infection. Following our previous study ([14]), $R_{\text {in }}$ was defined as the expected number of virions produced by a virus in a host with immunity $J$ :

$$
R_{i n}=n \cdot f(J, V) \cdot g(V)
$$

where $n$ is the effective number of virions per replication; $f(J, V)=\left[1-e^{p(V+1)}\right]^{r J}$ gives the probability of an ${ }_{364}$ infecting virus with binding avidity $V$ evading the immune response given host immunity $J$ as defined above; $\quad 365$ $g(V)=e^{\left(-a V^{b}\right)}$ gives the probability of successful replication within a host with binding avidity $V$; and $p, r, a \quad 366$ and $b$ are scaling constants $([14])$. Combining these probabilities with the effective number of virions per 367 replication gave the within-host reproductive number of viruses.

\section{Within-host receptor binding adaptation}

During the infectious period, binding avidity $V$ of each infectious virus adapted to the host's immunity $J$. The 370 change of binding avidity with time $\Delta V(t)$ was defined as the product of the rate of change of the virus binding ${ }_{371}$ avidity given by $d V / d t=k_{c}\left(d R_{i n} / d V\right)$ and time $\Delta t([14])$, where $d R_{i n} / d V$ was the fitness gradient with 372 respect to binding avidity, and $k_{c}$ quantifies the amount of genetic variance in receptor binding avidity within a 373 single host as a constant mediating adaptation rate. 
bioRxiv preprint doi: https://doi org/10.1101/2020.06 27.175190; this version posted June 29,2020. The copyright holder for this preprint (which was not certified by peer review) is the author/funder, who has granted bioRxiv a license to display the preprint in perpetuity. It is made available under aCC-BY-NC 4.0 International license.

simulating a single epidemic peak to represent a population with realistic heterogeneity in pre-existing

immunity. To match the distribution of partial immunity that is observed in human populations, we ran the simulation from a completely naive population to generate a distribution of host immunity. This initial-condition generating epidemic generated an attack rate of 54\%. Each infected individual received a boost to immunity drawn from a Poisson distribution with mean $\psi=8$ following infection, resulting in a distribution

Analyses were performed using a combination of R version 3.5.0 (R Foundation for Statistical Computing, 
bioRxiv preprint doi: https://doi org/10.1101/2020.06.27.175190; this version posted June 29,2020 . The copyright holder for this preprint (which was not certified by peer review) is the author/funder, who has granted bioRxiv a license to display the preprint in perpetuity. It is made available under aCC-BY-NC 4.0 International license.

Acknowledgements We thank Jonathan Yewdell for giving valuable suggestions and Scott Hensley for providing RDE binding avidity data. We also thank Katia Koelle and Christophe Fraser for valuable suggestions. This study was supported by grants from the City University of Hong Kong (\#7200573 and \#9610416).

\section{References}

[1] D. J. Smith. Mapping the Antigenic and Genetic Evolution of Influenza Virus. Science, 305(5682):371-376, 2004.

[2] Colin A. Russell, Terry C. Jones, Ian G. Barr, Nancy J. Cox, Rebecca J. Garten, Vicky Gregory, Ian D. Gust, Alan W. Hampson, Alan J. Hay, Aeron C. Hurt, Jan C. De Jong, Anne Kelso, Alexander I. Klimov, Tsutomu Kageyama, Naomi Komadina, Alan S. Lapedes, Yi P. Lin, Ana Mosterin, Masatsugu Obuchi, Takato Odagiri, Albert D.M.E. Osterhaus, Guus F. Rimmelzwaan, Michael W. Shaw, Eugene Skepner, Klaus Stohr, Masato Tashiro, Ron A.M. Fouchier, and Derek J. Smith. The global circulation of seasonal influenza A (H3N2) viruses. Science, 2008.

[3] Bryan T Grenfell. Unifying the Epidemiological and Evolutionary Dynamics of Pathogens. Science, 303(5656):327-332, 2004.

[4] Scott E Hensley, Suman R Das, Adam L Bailey, Loren M Schmidt, Heather D Hickman, Akila Jayaraman, Karthik Viswanathan, Rahul Raman, Ram Sasisekharan, Jack R Bennink, and Jonathan W Yewdell. Hemagglutinin receptor binding avidity drives influenza A virus antigenic drift. Science (New York, N.Y.), 326(5953):734-6, oct 2009.

[5] Jaclyn L Myers, Katherine S Wetzel, Susanne L Linderman, Yang Li, Colleen B Sullivan, and Scott E Hensley. Compensatory hemagglutinin mutations alter antigenic properties of influenza viruses. Journal of virology, 87(20):11168-72, 2013.

[6] Suman R Das, Scott E Hensley, Alexandre David, Loren Schmidt, James S Gibbs, Pere Puigbò, William L Ince, Jack R Bennink, and Jonathan W Yewdell. Fitness costs limit influenza A virus hemagglutinin glycosylation as an immune evasion strategy. Proceedings of the National Academy of Sciences of the United States of America, 108(51):E1417-22, dec 2011. 
bioRxiv preprint doi: https:/doi.org/10.1101/2020.06.27.175190; this version posted June 29,2020 . The copyright holder for this preprint (which was not certified by peer review) is the author/funder, who has granted bioRxiv a license to display the preprint in perpetuity. It is made available under aCC-BY-NC 4.0 International license.

[7] Nicholas C. Wu, Jia Xie, Tianqing Zheng, Corwin M. Nycholat, Geramie Grande, James C. Paulson, Richard A. Lerner, and Ian A. Wilson. Diversity of Functionally Permissive Sequences in the Receptor-Binding Site of Influenza Hemagglutinin. Cell Host and Microbe, 2017.

[8] Benjamin J. Cowling, Dennis K.M. Ip, Vicky J. Fang, Piyarat Suntarattiwong, Sonja J. Olsen, Jens Levy, Timothy M. Uyeki, Gabriel M. Leung, J. S. Malik Peiris, Tawee Chotpitayasunondh, Hiroshi Nishiura, and James Mark Simmerman. Aerosol transmission is an important mode of influenza A virus spread. Nature Communications, 2013.

[9] Andrew Varble, Randy A. Albrecht, Simone Backes, Marshall Crumiller, Nicole M. Bouvier, David Sachs, Adolfo García-Sastre, and Benjamin R. Tenoever. Influenza a virus transmission bottlenecks are defined by infection route and recipient host. Cell Host and Microbe, 16(5):691-700, 2014.

[10] D Hobson, R L Curry, A S Beare, A Ward-Gardner, and Esso Refinery. The role of serum haemagglutination-inhibiting antibody in protection against challenge infection with influenza A2 and B viruses. The Journal of hygiene, 70(4):767-77, 1972.

[11] Hsiang Yu Yuan, Marc Baguelin, Kin O. Kwok, Nimalan Arinaminpathy, Edwin van Leeuwen, and Steven Riley. The impact of stratified immunity on the transmission dynamics of influenza. Epidemics, 2017.

[12] Laurent Coudeville, Fabrice Bailleux, Benjamin Riche, Françoise Megas, Philippe Andre, and René Ecochard. Relationship between haemagglutination-inhibiting antibody titres and clinical protection against influenza: Development and application of a bayesian random-effects model. BMC Medical Research Methodology, 2010.

[13] Justin Lessler, Derek A.T. Cummings, Jonathan M. Read, Shuying Wang, Huachen Zhu, Gavin J.D. Smith, Yi Guan, Chao Qiang Jiang, and Steven Riley. Location-specific patterns of exposure to recent pre-pandemic strains of influenza A in southern China. Nature Communications, 2011.

[14] Hsiang-Yu Yuan and Katia Koelle. The evolutionary dynamics of receptor binding avidity in influenza A: a mathematical model for a new antigenic drift hypothesis. Philosophical transactions of the Royal Society of London. Series B, Biological sciences, 368(1614):20120204, 2013.

[15] A. Lavenu, M. Leruez-Ville, M. L. Chaix, P. Y. Boelle, S. Rogez, F. Freymuth, A. Hay, C. Rouzioux, and F. Carrat. Detailed analysis of the genetic evolution of influenza virus during the course of an epidemic. Epidemiology and Infection, 2006. 
bioRxiv preprint doi: https:/doi.org/10.1101/2020.06.27.175190; this version posted June 29,2020 . The copyright holder for this preprint (which was not certified by peer review) is the author/funder, who has granted bioRxiv a license to display the preprint in perpetuity. It is made available under aCC-BY-NC 4.0 International license.

[16] Peihua Cao, Chit Ming Wong, Kwok Hung Chan, Xiling Wang, King Pan Chan, Joseph Sriyal Malik Peiris, Leo Lit Man Poon, and Lin Yang. Age-specific genetic and antigenic variations of influenza A viruses in Hong Kong, 2013-2014. Scientific Reports, 2016.

[17] Andrew Rambaut, Oliver G. Pybus, Martha I. Nelson, Cecile Viboud, Jeffery K. Taubenberger, and Edward C. Holmes. The genomic and epidemiological dynamics of human influenza A virus. Nature, 2008.

[18] Samir Bhatt, Edward C. Holmes, and Oliver G. Pybus. The genomic rate of molecular adaptation of the human influenza A virus. Molecular Biology and Evolution, 2011.

[19] Anna Cushing, Amanda Kamali, Mark Winters, Erik S. Hopmans, John M. Bell, Susan M. Grimes, Li C. Xia, Nancy R. Zhang, Ronald B. Moss, Mark Holodniy, and Hanlee P. Ji. Emergence of Hemagglutinin Mutations During the Course of Influenza Infection. Scientific Reports, 2015.

[20] Ashley Sobel Leonard, Micah T. McClain, Gavin J. D. Smith, David E. Wentworth, Rebecca A. Halpin, Xudong Lin, Amy Ransier, Timothy B. Stockwell, Suman R. Das, Anthony S. Gilbert, Robert Lambkin-Williams, Geoffrey S. Ginsburg, Christopher W. Woods, and Katia Koelle. Deep Sequencing of Influenza A Virus from a Human Challenge Study Reveals a Selective Bottleneck and Only Limited Intrahost Genetic Diversification. Journal of Virology, 2016.

[21] Trevor Bedford, Andrew Rambaut, and Mercedes Pascual. Canalization of the evolutionary trajectory of the human influenza virus. BMC Biology, 2012.

[22] B. F. Koel, D. F. Burke, T. M. Bestebroer, S. van der Vliet, G. C. M. Zondag, G. Vervaet, E. Skepner, N. S. Lewis, M. I. J. Spronken, C. A. Russell, M. Y. Eropkin, A. C. Hurt, I. G. Barr, J. C. de Jong, G. F. Rimmelzwaan, A. D. M. E. Osterhaus, R. A. M. Fouchier, and D. J. Smith. Substitutions Near the Receptor Binding Site Determine Major Antigenic Change During Influenza Virus Evolution. Science, 342(6161):976-979, 2013.

[23] Nimalan Arinaminpathy and Bryan Grenfell. Dynamics of glycoprotein charge in the evolutionary history of human influenza. PloS one, 5(12):e15674, jan 2010.

[24] Yuki Kobayashi and Yoshiyuki Suzuki. Compensatory evolution of net-charge in influenza A virus hemagglutinin. PLoS ONE, 7(7), 2012. 
bioRxiv preprint doi: https:/doi.org/10.1101/2020.06.27.175190; this version posted June 29,2020 . The copyright holder for this preprint (which was not certified by peer review) is the author/funder, who has granted bioRxiv a license to display the preprint in perpetuity. It is made available under aCC-BY-NC 4.0 International license.

[25] A S Gambaryan, M N Matrosovich, C A Bender, and E D Kilbourne. Differences in the biological phenotype of low-yielding (L) and high-yielding $(\mathrm{H})$ variants of swine influenza virus $\mathrm{A} / \mathrm{NJ} / 11 / 76$ are associated with their different receptor-binding activity. Virology, 247(2):223-31, 1998.

[26] B. S. Chambers, Y. Li, R. L. Hodinka, and S. E. Hensley. Recent H3N2 Influenza Virus Clinical Isolates Rapidly Acquire Hemagglutinin or Neuraminidase Mutations When Propagated for Antigenic Analyses. Journal of Virology, 88(18):10986-10989, 2014.

[27] E Ghedin, N A Sengamalay, M Shumway, J Zaborsky, T Feldblyum, V Subbu, D J Spiro, J Sitz, H Koo, P Bolotov, D Dernovoy, T Tatusova, Y Bao, K St George, J Taylor, D J Lipman, C M Fraser, J K Taubenberger, and S L Salzberg. Large-scale sequencing of human influenza reveals the dynamic nature of viral genome evolution. Nature, 437(7062):1162-1166, 2005.

[28] Yiming Bao, Pavel Bolotov, Dmitry Dernovoy, Boris Kiryutin, Leonid Zaslavsky, Tatiana Tatusova, Jim Ostell, and David Lipman. The influenza virus resource at the National Center for Biotechnology Information. Journal of virology, 82(2):596-601, 2008.

[29] Adam J. Kucharski, Justin Lessler, Jonathan M. Read, Huachen Zhu, Chao Qiang Jiang, Yi Guan, Derek A T Cummings, and Steven Riley. Estimating the Life Course of Influenza A(H3N2) Antibody Responses from Cross-Sectional Data. PLoS Biology, 13(3), 2015.

[30] Adam J. Kucharski and Julia R. Gog. The Role of Social Contacts and Original Antigenic Sin in Shaping the Age Pattern of Immunity to Seasonal Influenza. PLoS Computational Biology, 8(10), 2012.

[31] Justin Lessler, Steven Riley, Jonathan M. Read, Shuying Wang, Huachen Zhu, Gavin J.D. Smith, Yi Guan, Chao Qiang Jiang, and Derek A.T. Cummings. Evidence for antigenic seniority in influenza A (H3N2) antibody responses in southern China. PLoS Pathogens, 8(7):26, 2012.

[32] J. M. Fonville, S. H. Wilks, S. L. James, A. Fox, M. Ventresca, M. Aban, L. Xue, T. C. Jones, Le N. M. H., Pham Q. T., Tran N. D., Y. Wong, A. Mosterin, L. C. Katzelnick, D. Labonte, Le T. T., G. van der Net, E. Skepner, C. A. Russell, T. D. Kaplan, G. F. Rimmelzwaan, N. Masurel, J. C. de Jong, A. Palache, W. E. P. Beyer, Le Q. M., Nguyen T. H., H. F. L. Wertheim, A. C. Hurt, A. D. M. E. Osterhaus, I. G. Barr, R. A. M. Fouchier, P. W. Horby, and D. J. Smith. Antibody landscapes after influenza virus infection or vaccination. Science, 346(6212):996-1000, 2014.

[33] Alexei J Drummond and Andrew Rambaut. BEAST: Bayesian evolutionary analysis by sampling trees. BMC Evolutionary Biology, 7(1):214, 2007. 
bioRxiv preprint doi: https:/doi.org/10.1101/2020.06.27.175190; this version posted June 29,2020 . The copyright holder for this preprint (which was not certified by peer review) is the author/funder, who has granted bioRxiv a license to display the preprint in perpetuity. It is made available under aCC-BY-NC 4.0 International license.

[34] Motoo Kimura. Possibility of extensive neutral evolution under stabilizing selection with special reference to nonrandom usage of synonymous codons. Proceedings of the National Academy of Sciences of the United States of America, 78(9):5773-5777, 1981.

[35] Sir Fisher, Ronald Aylmer. The genetical theory of natural selection. Oxford University Press, 1930. https://www.biodiversitylibrary.org/bibliography/27468.

[36] Brian Charlesworth. Stabilizing selection, purifying selection, and mutational bias in finite populations. Genetics, 194(4):955-971, 2013.

[37] Y. P. Lin, X. Xiong, S. A. Wharton, S. R. Martin, P. J. Coombs, S. G. Vachieri, E. Christodoulou, P. A. Walker, J. Liu, J. J. Skehel, S. J. Gamblin, A. J. Hay, R. S. Daniels, and J. W. McCauley. Evolution of the receptor binding properties of the influenza A(H3N2) hemagglutinin. Proceedings of the National Academy of Sciences, 109(52):21474-21479, 2012.

[38] Y. Li, D. L. Bostick, C. B. Sullivan, J. L. Myers, S. B. Griesemer, K. StGeorge, J. B. Plotkin, and S. E. Hensley. Single Hemagglutinin Mutations That Alter both Antigenicity and Receptor Binding Avidity Influence Influenza Virus Antigenic Clustering. Journal of Virology, 87(17):9904-9910, 2013.

[39] Jorge M. Dinis, Nicholas W. Florek, Omolayo O. Fatola, Louise H. Moncla, James P. Mutschler, Olivia K. Charlier, Jennifer K. Meece, Edward A. Belongia, and Thomas C. Friedrich. Deep Sequencing Reveals Potential Antigenic Variants at Low Frequencies in Influenza A Virus-Infected Humans. Journal of Virology, 2016.

[40] Kari Debbink, John T. McCrone, Joshua G. Petrie, Rachel Truscon, Emileigh Johnson, Emily K. Mantlo, Arnold S. Monto, and Adam S. Lauring. Vaccination has minimal impact on the intrahost diversity of H3N2 influenza viruses. PLoS Pathogens, 2017.

[41] Alvin X. Han, Sebastian Maurer-Stroh, and Colin A. Russell. Individual immune selection pressure has limited impact on seasonal influenza virus evolution. Nature Ecology and Evolution, 2019.

[42] Maia Martcheva, Necibe Tuncer, and Colette St Mary. Coupling Within-Host and Between-Host Infectious Diseases Models. Biomath, 4(2):Article ID: 1510091, 2015.

[43] Julia R. Gog, Lorenzo Pellis, James L.N. Wood, Angela R. McLean, Nimalan Arinaminpathy, and James O. Lloyd-Smith. Seven challenges in modeling pathogen dynamics within-host and across scales. Epidemics, 10:45-48, 2015. 
bioRxiv preprint doi: https:/doi.org/10.1101/2020 $06.27 .175190 \cdot$ this version posted June 29,2020 . The copyright holder for this preprint (which was not certified by peer review) is the author/funder, who has granted bioRxiv a license to display the preprint in perpetuity. It is made available under aCC-BY-NC 4.0 International license.

[44] Dylan H. Morris, Velislava N. Petrova, Fernando W. Rossine, Edyth Parker, Bryan T. Grenfell, Richard A. Neher, Simon A. Levin, and Colin A. Russell. Asynchrony between virus diversity and antibody selection limits influenza virus evolution. bioRxiv, page 2020.04.27.064915, apr 2020.

[45] Katrina A. Lythgoe, Lorenzo Pellis, and Christophe Fraser. Is Hiv Short-Sighted? Insights From A Multistrain Nested Model. Evolution, 67(10):2769-2782, 2013.

[46] Katrina A. Lythgoe, Andy Gardner, Oliver G. Pybus, and Joe Grove. Short-Sighted Virus Evolution and a Germline Hypothesis for Chronic Viral Infections. Trends in Microbiology, 25(5):336-348, 2017.

[47] Marta Luksza and Michael Lässig. A predictive fitness model for influenza. Nature, 507(7490):57-61, 2014.

[48] Katia Koelle and David A. Rasmussen. The effects of a deleterious mutation load on patterns of influenza A/H3N2's antigenic evolution in humans. eLife, 4(September), 2015.

[49] Jesse D. Bloom and Matthew J. Glassman. Inferring Stabilizing Mutations from Protein Phylogenies: Application to Influenza Hemagglutinin. PLoS Computational Biology, 5(4), 2009.

[50] Marc Baguelin, Stefan Flasche, Anton Camacho, Nikolaos Demiris, Elizabeth Miller, and W. John Edmunds. Assessing Optimal Target Populations for Influenza Vaccination Programmes: An Evidence Synthesis and Modelling Study. PLoS Medicine, 10(10), 2013.

[51] A Rohatgi. WebPlotDigitalizer: HTML5 based online tool to extract numerical data from plot images. Version 3., 2012.

[52] Alexei J. Drummond, Marc A. Suchard, Dong Xie, and Andrew Rambaut. Bayesian phylogenetics with BEAUti and the BEAST 1.7. Molecular Biology and Evolution, 29(8):1969-1973, 2012.

[53] Robert M. Jacobson, Diane E. Grill, Ann L. Oberg, Pritish K. Tosh, Inna G. Ovsyannikova, and Gregory A. Poland. Profiles of influenza A/H1N1 vaccine response using hemagglutination-inhibition titers. Human Vaccines and Immunotherapeutics, 11(4):961-969, 2015.

[54] Daniel J Wilson. The harmonic mean p-value for combining dependent tests. Proceedings of the National Academy of Sciences of the United States of America, Jan 2019. 
bioRxiv preprint doi: https://doi.org/10.1101/2020.06.27.175190; this version posted June 29, 2020. The copyright holder for this preprint (which was not certified by peer review) is the author/funder, who has granted bioRxiv a license to display the preprint in perpetuity. It is made available under aCC-BY-NC 4.0 International license.

\section{Supplementary}

Supplementary Methods. Further description of individual-based model implementation. 
bioRxiv preprint doi: https://doi.org/10.1101/2020.06.27.175190; this version posted June 29, 2020. The copyright holder for this preprint (which was not certified by peer review) is the author/funder, who has granted bioRxiv a license to display the preprint in perpetuity. It is made available under aCC-BY-NC 4.0 International license.

Table S1. Change in binding avidity from HA mutations by net charge category. The odds ratio of increasing receptor binding avidity for mutations with positive compared with non-positive net charge change was given. (Odds ratio $=11.27 ; 95 \%$ confidence interval: 3.14-48.5; p-value $<0.001$ using Fisher's exact test). Dec or Neu indicates decreased or neutral effects on receptor binding avidity and Inc indicates increased effects on receptor binding. 70 mutations were used after removing 3 duplicates and 1 reversed mutation.

\begin{tabular}{lrrr}
\hline \hline & & & \\
Net charge & Dec or Neu & Inc & Total \\
\hline$\leq 0$ & 36 & 11 & 47 \\
$>0$ & 5 & 18 & 23 \\
Total & 41 & 29 & 70 \\
\hline
\end{tabular}


Table S2. Comparison of the net charge distribution of internal and external nodes on the phylogenetic tree. The difference of the number of strains that changed net charge (\# Without net charge change and \# With net charge change) between external nodes and internal nodes was tested using Fisher's exact test, giving an odds ratio (odds of higher number of net charge changes at external nodes relative to internal nodes) of 1.64 (95\% CI: 1.14-2.35; Fisher's exact test; $p$-value $=0.009 ; n=1370$ ). The number of internal (or external) nodes that fit this definition is expressed as a percentage of the total number of internal (or external) nodes. Among the nodes with net charge change, the number of positive Pos and negative Neg changes are shown. High net charge is defined as an absolute net charge greater than 18 (median of all 1370 samples is 17). The average net charge and standard deviation of internal and external nodes is shown.

\begin{tabular}{lllllll}
\hline \hline & $\begin{array}{l}\text { \# Without } \\
\text { net charge } \\
\text { change }\end{array}$ & $\begin{array}{l}\text { \# With net } \\
\text { charge } \\
\text { change }\end{array}$ & $\begin{array}{l}\text { \# Pos } \\
\text { changes }\end{array}$ & $\begin{array}{l}\text { \# Neg } \\
\text { changes }\end{array}$ & $\begin{array}{l}\text { Prop high } \\
\text { net charge } \\
(\%)\end{array}$ & $\begin{array}{l}\text { Avg net } \\
\text { charge }\end{array}$ \\
\hline Internal & $631(92.3 \%)$ & $53(7.7 \%)$ & 15 & 38 & 20.0 & $17.52 \pm 1.06$ \\
External & $603(87.9 \%)$ & $83(12.1 \%)$ & 32 & 51 & 18.7 & $17.45 \pm 1.09$ \\
\hline
\end{tabular}


Table S3. Comparison of the number of nodes with and without a significant change in binding avidity. Binding avidity changes were calculated by comparing each node's binding avidity relative to their direct ancestors'. A node's binding avidity was defined to have a significant change when the difference from its direct ancestor's binding avidity exceeded a threshold of 0.3 in $\Delta V$, resulting in approximately $20 \%$ of nodes demonstrating a significant change in binding avidity. Results shown are averaged over 200 simulated phylogenetic trees. Each simulated tree was thinned to give 300 viruses as external nodes. Taking equal weights, the harmonic mean p-value ([54] $)$ calculated from individual Fisher's exact test on each simulation was $<0.001$. Odds ratio from Fisher's exact test on the simulation means was 2.36 (95\% CI: 1.50-3.74; p-value <0.001).

\begin{tabular}{lcc}
\hline \hline & $\begin{array}{c}\text { Without significant change in } \\
\text { binding avidity }\end{array}$ & $\begin{array}{c}\text { With significant change in } \\
\text { binding avidity }\end{array}$ \\
\hline & & \\
Internal & $261.5 \pm 6.5(87.7 \pm 2.2 \%)$ & $36.5 \pm 6.5(12.3 \pm 2.2 \%)$ \\
External & $225.4 \pm 9.1(75.1 \pm 3.0 \%)$ & $74.6 \pm 9.1(24.9 \pm 3.0 \%)$ \\
\hline
\end{tabular}


Table S4. List of parameters used in individual-based model simulations.

\begin{tabular}{|c|c|c|}
\hline Parameter name & symbol & values \\
\hline Total human population size & $N$ & 500,000 \\
\hline Birth \& death rate (per day) & $\mu$ & $1 /(70 * 365)$ \\
\hline Recovery rate (per day) & $\gamma$ & $1 / 3.3$ \\
\hline Waning rate (per day) & $\omega$ & $1 / 25$ \\
\hline Initial number of seeds & $I_{t=0}$ & 100 \\
\hline Antibody boosting & $\psi$ & 8 \\
\hline Host immunity & $J$ & varied \\
\hline Initial antigenic mutant distance & $\delta$ & 3 \\
\hline Effective number of transmitted virions & $\sigma$ & 1 \\
\hline Effective number of virions per replication & $n$ & 4 \\
\hline Contact rate (per day) & $c$ & 0.7 \\
\hline Binding avidity adaptation rate (per day) & $k_{c}$ & 0.3 \\
\hline Maximum achievable host immunity & $j_{\max }$ & 40 \\
\hline
\end{tabular}


bioRxiv preprint doi: https://doi.org/10.1101/2020.06.27.175190; this version posted June 29, 2020. The copyright holder for this preprint (which was not certified by peer review) is the author/funder, who has granted bioRxiv a license to display the preprint in perpetuity. It is made available under aCC-BY-NC 4.0 International license.

Table S5. List of all collected mutations with corresponding binding avidity (RDE). (Attached as an excel file) 
bioRxiv preprint doi: https://doi.org/10.1101/2020 06.27 .175190 , this version posted June 29,2020 . The copyright holder for this preprint (which was not certified by peer review) is the author/funder, who has granted bioRxiv a license to display the preprint in perpetuity. It is made available under aCC-BY-NC 4.0 International license.

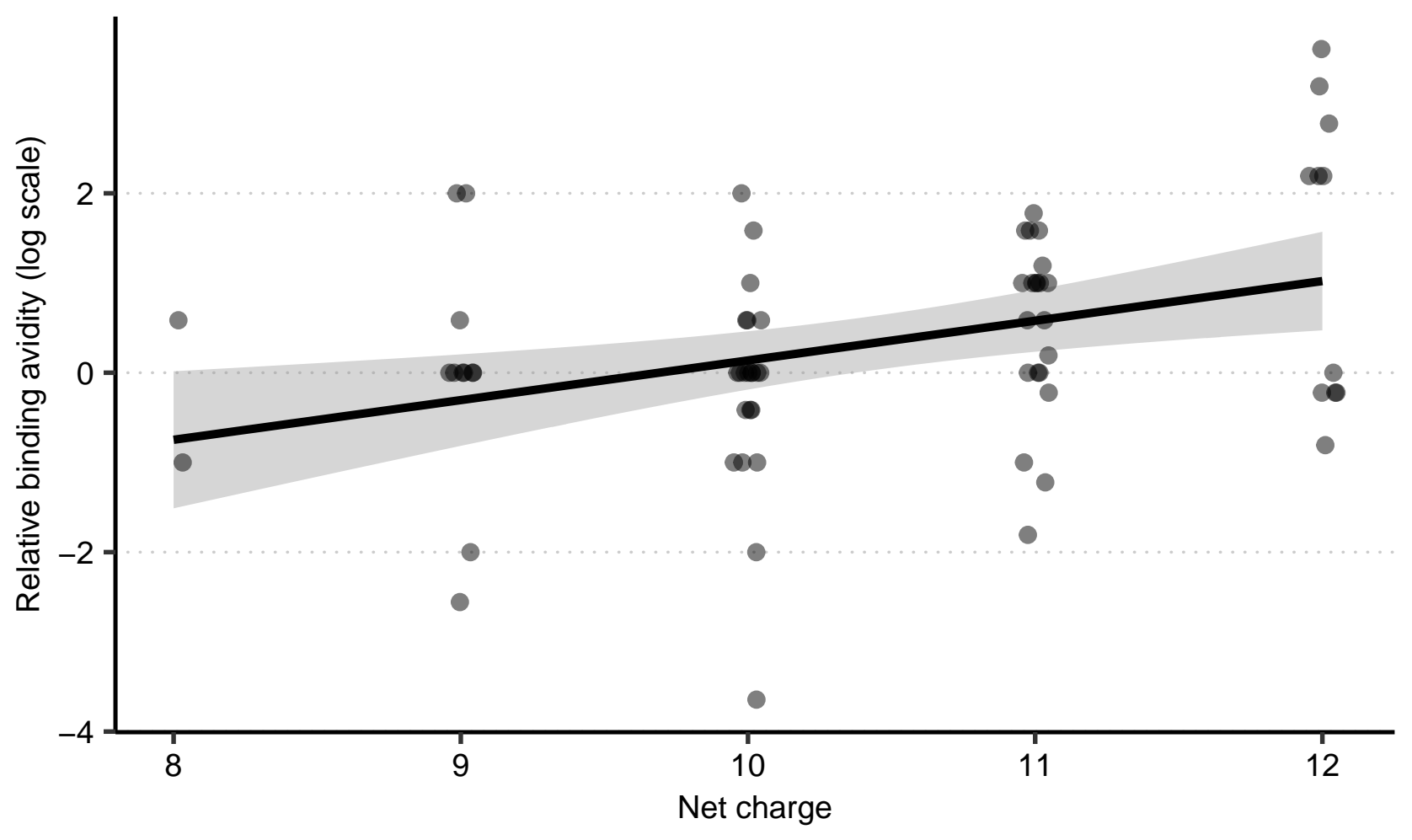

Figure S1. Relative binding avidity against net charge of A/H1N1 HA. Relative binding avidity was calculated as the log ratio of RDE activity of the mutant relative to the wild type A/H1N1 PR8. Net charges of all 67 A/H1N1 mutant strains were calculated based on their amino acid sequences using positions 18 to 342 of HA1. Pearson correlation coefficient was $r=0.353$ (95\% confidence interval: $0.123-0.547$; $p$-value $=0.003$ ) and slope of the line was 0.282 ( $\mathrm{p}$-value $=0.002$ using a one-tailed test to test whether the slope was greater than zero). 


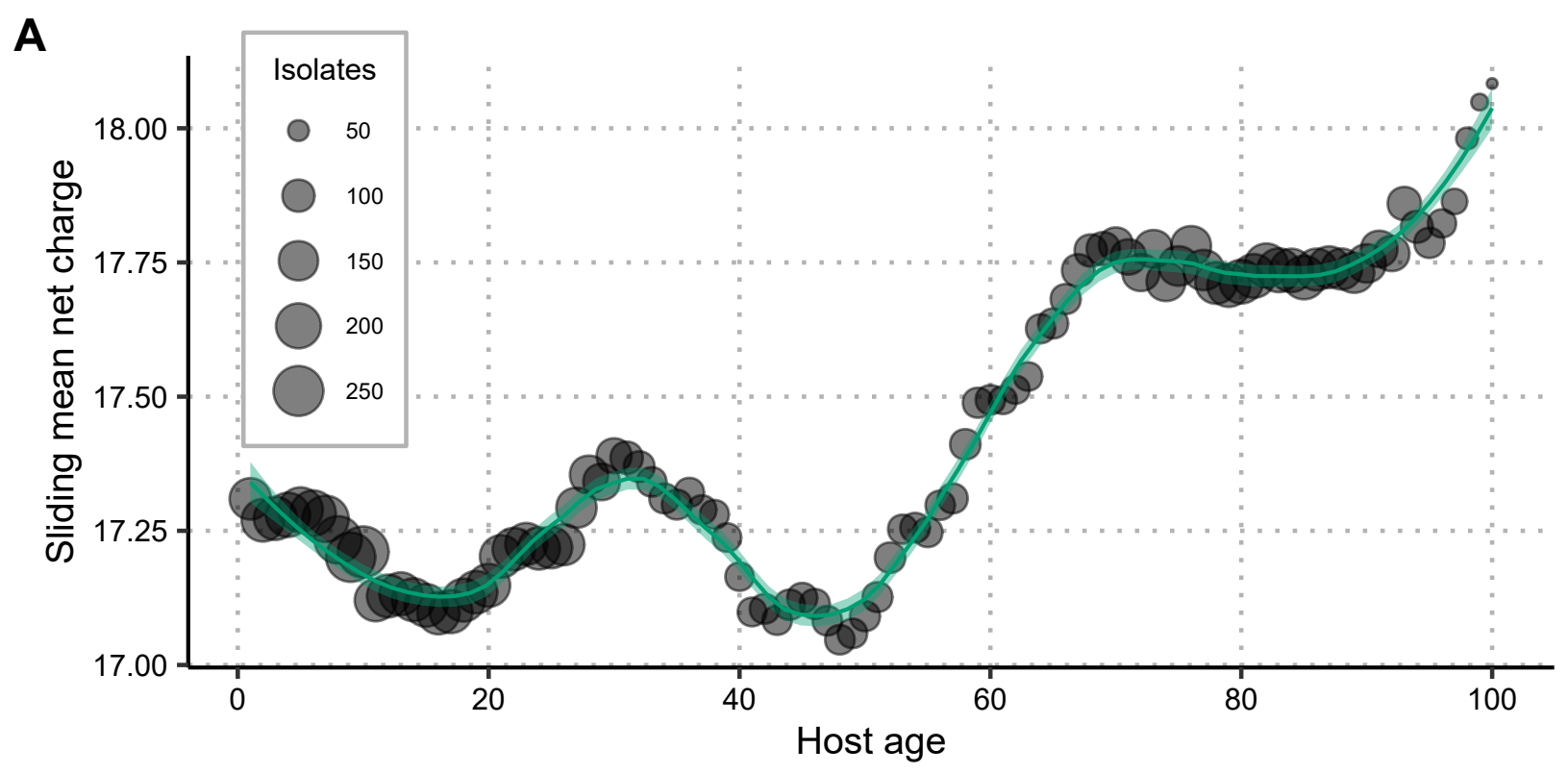

B

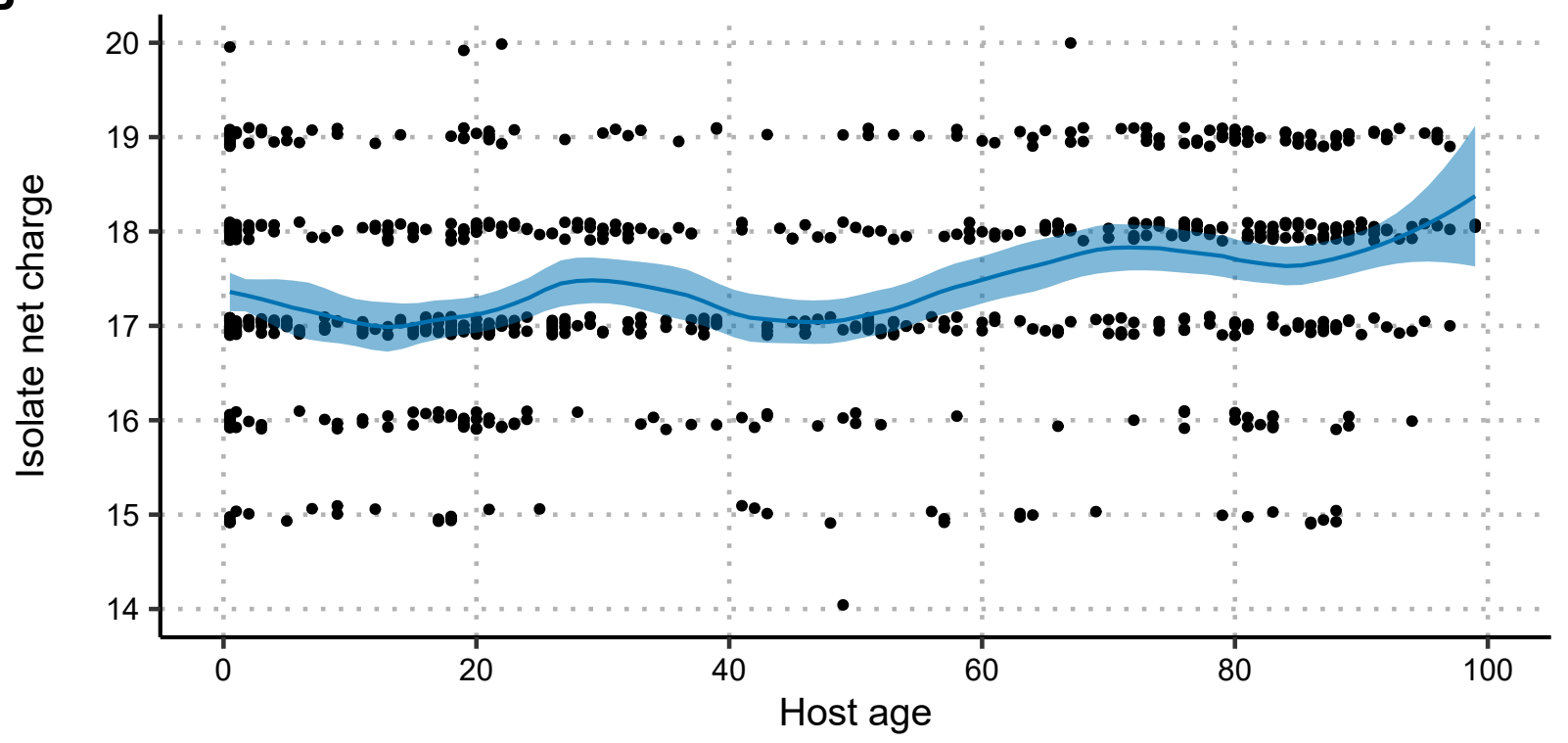

Figure S2. Virus net charge distribution by age of host. (A) Sliding mean net charge by age. Each circle represents the mean net charge calculated from a sliding window of size 10 centered on each year from 1 to 100 yo. The size of circle represents the number of strains in a given sliding window. Green line and shaded region show a LOESS smoothing curve fit with $95 \%$ confidence interval (CI) to the calculated values using a span value of 0.3. (B) Isolate net charge by age of host. Each point is one virus isolate slightly jittered in the y-axis. Blue line and shaded region show LOESS smoothing curve fit with $95 \%$ CI using a span value of 0.3 . 759 virus sequences and age metadata were obtained from the Influenza Genome Sequencing Project ([27]) and the Influenza Virus Resource Database ([28]). 
bioRxiv preprint doi: https://doi.org/10.1101/2020.06.27.175190; this version posted June 29, 2020. The copyright holder for this preprint (which was not certified by peer review) is the author/funder, who has granted bioRxiv a license to display the preprint in perpetuity. It is made available under aCC-BY-NC 4.0 International license.

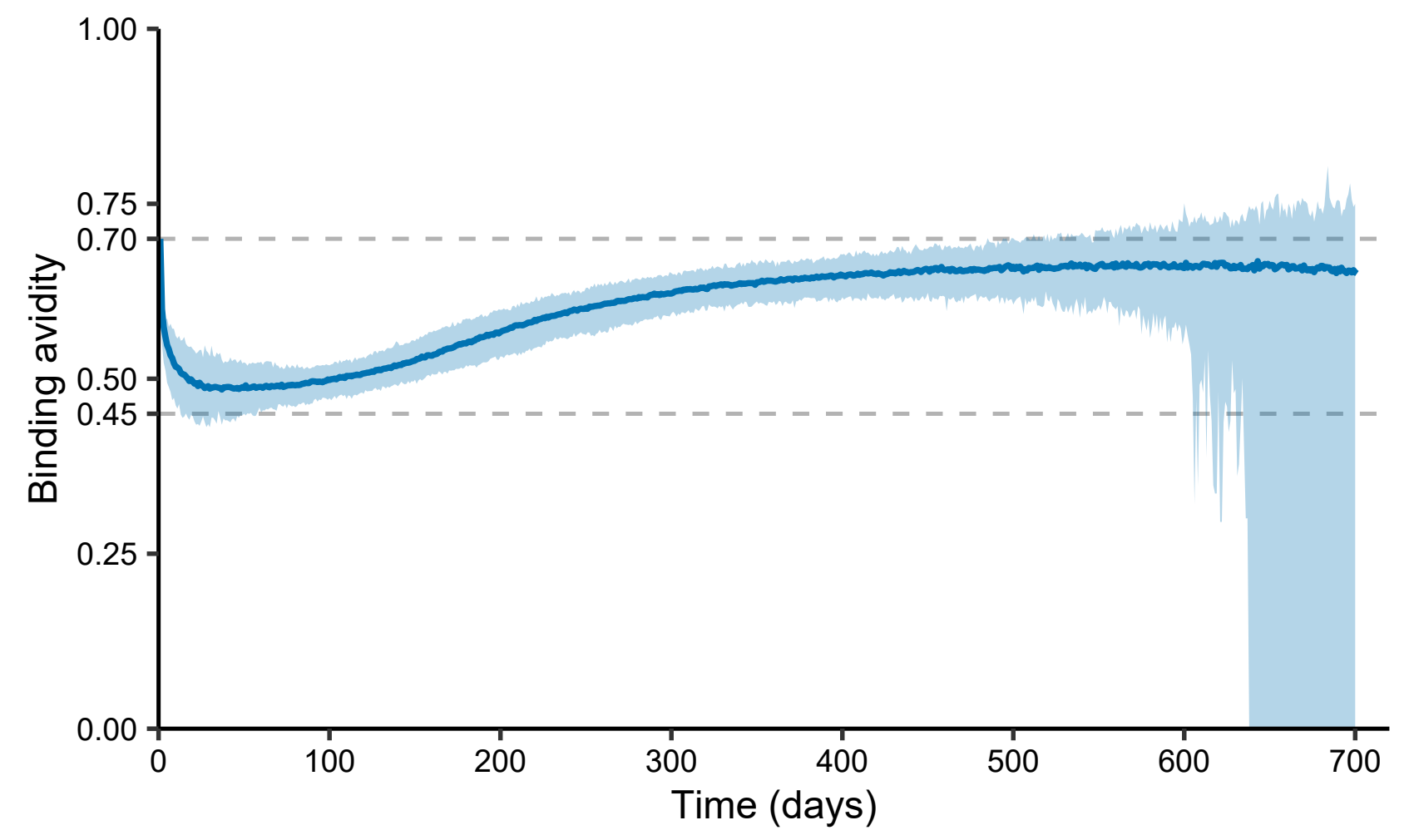

Figure S3. Change in mean binding avidity of all extant viruses over the course of simulated epidemics. Dark blue line and light blue region show median and $95 \%$ quantiles for the estimated means produced by 200 model runs in Figure 5. Binding avidity was recorded as 0 once there were no more infected individuals. 
bioRxiv preprint doi: https://doi.org/10.1101/2020.06.27.175190; this version posted June 29, 2020. The copyright holder for this preprint (which was not certified by peer review) is the author/funder, who has granted bioRxiv a license to display the preprint in perpetuity. It is made available under aCC-BY-NC 4.0 International license.

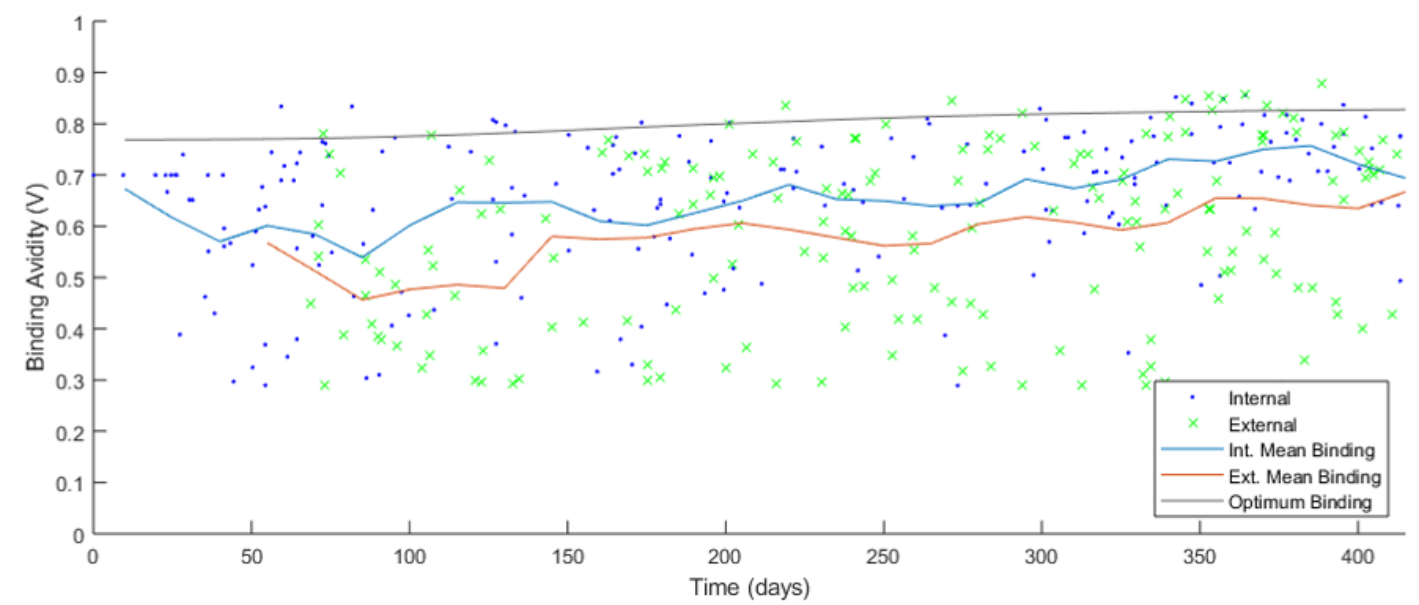

Figure S4. Binding avidity over time in a typical model simulation. Parameter values are the same as those for Figure 4. Blue dots represent internal nodes from the viral phylogeny. Green dots represent external tips from the viral phylogeny. Blue line represents mean binding avidity from internal nodes. Red line represents mean binding avidity from external nodes. Gray line shows the optimum virus binding avidity that will produce the greatest number of infections at the population level. 
bioRxiv preprint doi: https://doi.org/10.1101/2020.06.27.175190; this version posted June 29, 2020. The copyright holder for this preprint (which was not certified by peer review) is the author/funder, who has granted bioRxiv a license to display the preprint in perpetuity. It is made available under aCC-BY-NC 4.0 International license.
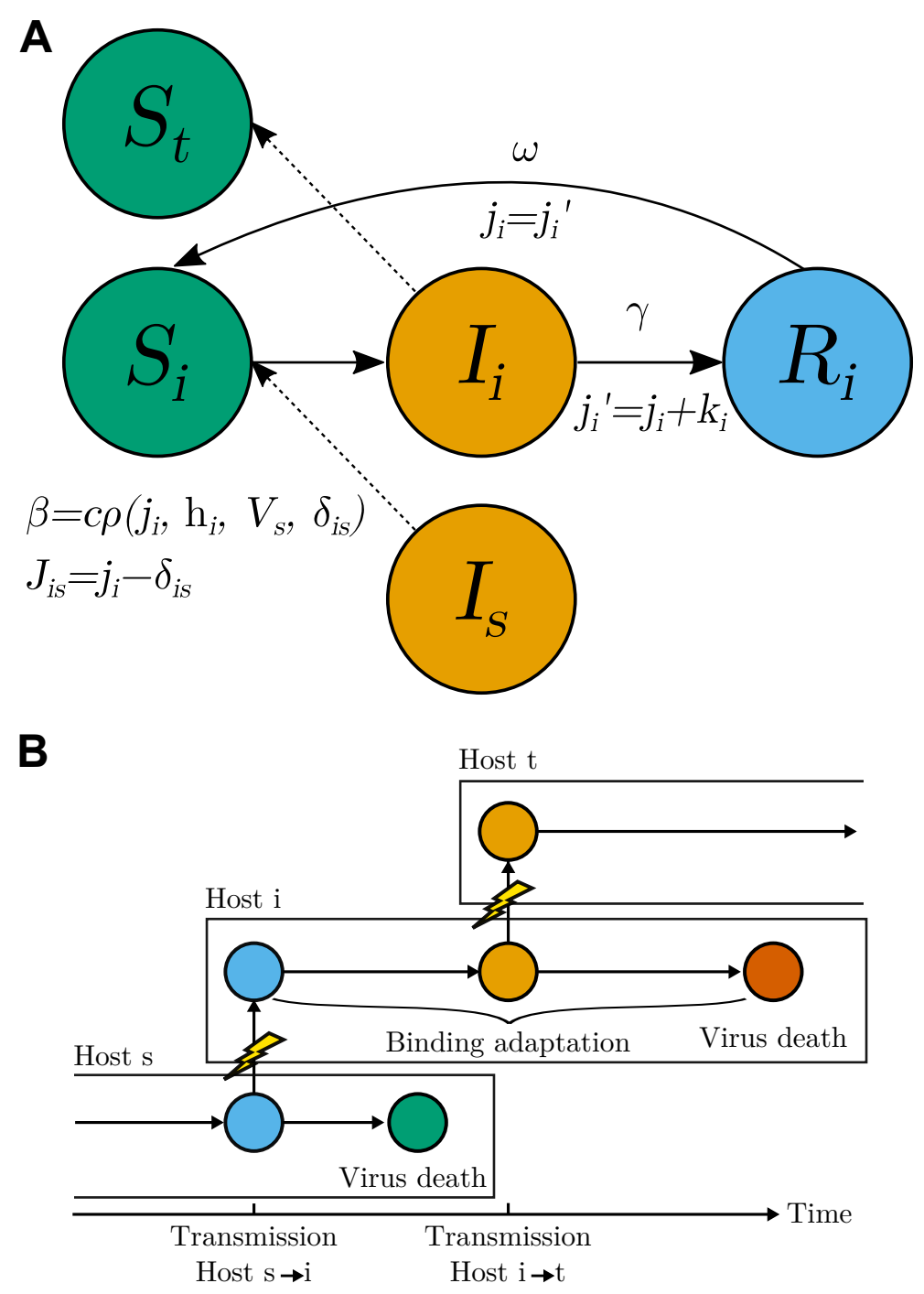

Figure S5. Schema of disease transmission in the individual-based model. The schema represents infections from host $s$ to $i$ then to $t$. (A) The status of a host during an infection is shown as an SIRS model ( $\mathrm{S}=$ Susceptible; $\mathrm{I}=\mathrm{Infected} ; \mathrm{R}=\mathrm{Recovered}$ ). $j_{i}$ is the immunity of the host $i$ against all previous infecting viruses. $J_{i s}$ is the immunity of the susceptible host $i$ against infection from the infected source $s . \delta_{i s}$ is the smallest antigenic distance from the virus affecting host $i$ to viruses in the infection history of host $i, \mathbf{h}_{i} . V_{s}$ is the binding avidity of the virus from the source $s$ at time of transmission. $k_{i}$ is the antibody boost upon recovery and $j^{\prime}$ represents the boosted immunity. Epidemiological parameters: $c$ is the contact rate, $\rho$ is the probability of infection (shown here as a function of host and virus properties), $\gamma$ is the recovery rate, and $\omega$ is the waning rate of fully protective transient immunity. (B) Viruses with different receptor binding avidities are tracked within and between all individual hosts. Each rectangle represents the infection period of a particular host. After transmission (lightening symbols), a virus is produced with the same binding avidity as it had in the previous host at the time of transmission (blue and orange circles). Over the course of the infection, binding avidity adapts to the host's immunity level. Circle colors represent changes in virus binding avidity over the infectious period. The virus dies upon host recovery. 
bioRxiv preprint doi: https://doi.org/10.1101/2020.06.27.175190; this version posted June 29, 2020. The copyright holder for this preprint (which was not certified by peer review) is the author/funder, who has granted bioRxiv a license to display the preprint in perpetuity. It is made available under aCC-BY-NC 4.0 International license.

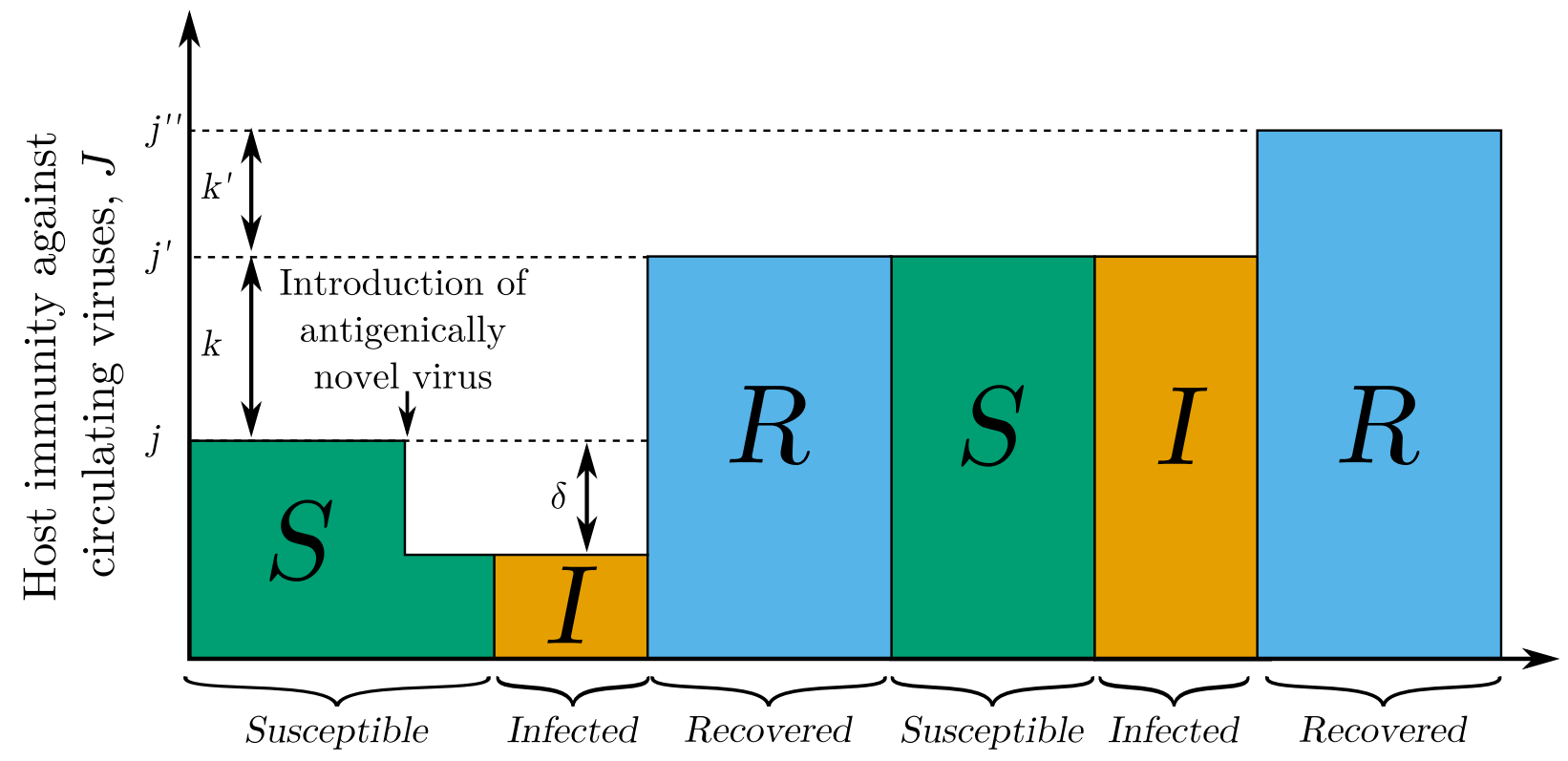

Figure S6. Schema of an individual host's immunity over time. Colored rectangles show host infection status over time (note that the width of each state does not represent actual time spent in that state). $j$ represents the antibody titer available against a virus with no antigenic distance to any virus that the host has been infected with previously $(\delta=0)$. If an antigenic mutant emerges such that the shortest antigenic distance between that virus mutant and the viruses that previously infected the host is $\delta$, then the host has reduced immunity $(J=j-\delta$ ) upon contact. The marked point shows the drop in immunity $J$ against circulating viruses upon introduction of an antigenically novel virus into the population. Once the host recovers from infection, host immunity to previously encountered viruses $J$ is boosted to a higher level from antibody boosting $k$ $\left(j^{\prime}=j+k\right)$ and the virus is added to the host's infection history $\mathbf{h}$. The host then has full immunity $\left(J=j^{\prime}\right)$ against all viruses in the infection history, including the recent mutant $(\delta=0)$. If the host is reinfected with the same virus, host immunity is boosted again $\left(j^{\prime \prime}=j^{\prime}+k^{\prime}\right)$. 
bioRxiv preprint doi: https://doi.org/10.1101/2020.06.27.175190; this version posted June 29, 2020. The copyright holder for this preprint (which was not certified by peer review) is the author/funder, who has granted bioRxiv a license to display the preprint in perpetuity. It is made available under aCC-BY-NC 4.0 International license.

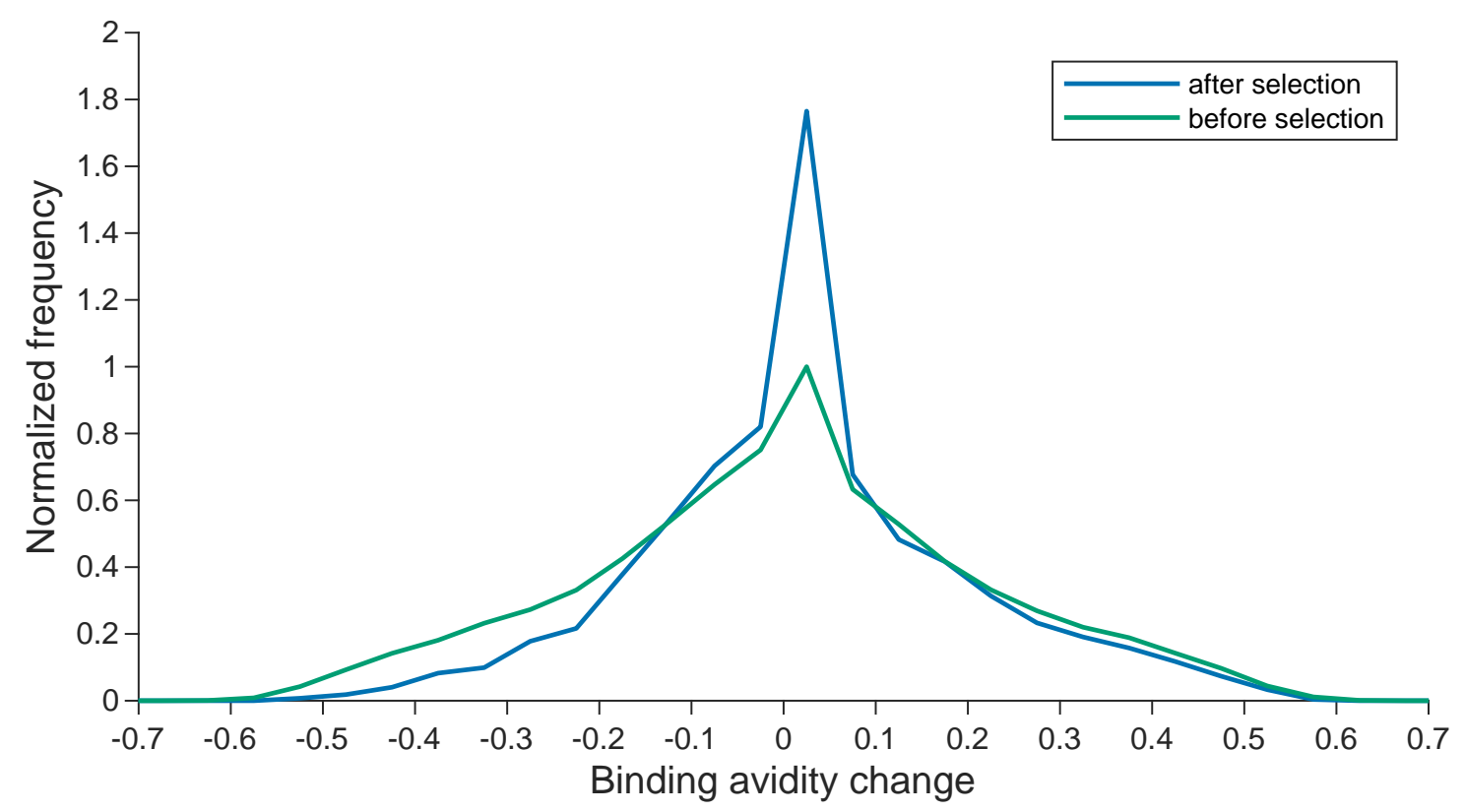

Figure S7. Changes in binding avidity of nodes before (defined as all nodes) and after (defined as internal nodes in the main trunk only) selection, averaged from 200 simulated phylogenetic trees. Y-axis denotes the absolute frequency divided by the mode for nodes before selection. 